\title{
The Management of Tree Root Systems in Urban and Suburban Settings II: A Review of Strategies to Mitigate Human Impacts
}

\author{
Gary W. Watson, Angela M. Hewitt, Melissa Custic, and Marvin Lo
}

\begin{abstract}
Root systems of nearly all trees in the built environment are subject to impacts of human activities that can affect tree health and reduce longevity. These influences are present from early stages of nursery development and throughout the life of the tree. Reduced root systems from root loss or constriction can reduce stability and increase stress. Natural infection of urban tree roots after severing has not been shown to lead to extensive decay development. Roots often conflict with infrastructure in urban areas because of proximity. Strategies to provide root space under pavements and to reduce pavement heaving have been developed, but strategies for prevention of foundation and sewer pipe damage are limited to increasing separation or improved construction.

Key Words. Ground-Penetrating Radar; Infrastructure Damage; Root Architecture; Root Decay; Root Defects; Rooting Space; Root Flare; Root Severing; Stability.
\end{abstract}

Tree root systems are generally shallow and widespread (Day et al. 2010). Human activity around trees frequently impacts tree root systems, decreasing tree health and reducing longevity compared to trees on natural sites. Construction and repair of infrastructure often severs tree roots. The presence of buildings and pavements can restrict root systems with detrimental effects on both the tree and the structure. Urban landscape design and maintenance can be very different than the natural environment to which the trees are adapted. Root architecture is altered by nursery production and transplanting, which can affect the tree throughout its life. The management challenge is to avoid or reduce these impacts through proper management, including minimizing injury to existing roots, speeding root regrowth after severing occurs, and maximizing the quality and quantity of root space in design.

\section{ROOT ARCHITECTURE AND STABILITY}

Tree stability depends heavily on both root system architecture and the anchorage of roots in the soil. Root/soil resistance gives rise to the characteris- tic mass of roots and soil seen on uprooted trees, known as the root plate. The anchorage strength of a tree root system has four components: 1) the mass of the roots and soil levered out of the ground, 2) the strength of the soil and depth of root penetration under the root plate, 3 ) the resistance to failure in tension of tree roots on the windward side as the upward movement of the root-soil plate causes roots to pull out of the soil with or without first breaking, and 4) the length of the lever arm (where the roots hinge) on the leeward side, which is affected by root diameter and resistance to bending of the tree roots (Coutts 1983; Coutts 1986; Blackwell et al. 1990; Kodrik and Kodrik 2002). A change in one feature can affect several others. Thus, an increase in root plate diameter will increase the weight component, the length of lever arm between the trunk and the roots around the perimeter of the plate, and the area of root/soil contact under the plate. As each of these anchorage components increases, the greater the force needed to tip up the root plate. Uneven distribution (large sections without roots) reduces anchorage (Sundstrom and Keane 1999).

Environmental factors influence root architecture and stability. If roots penetrate deeper, as can 
be the case in sandy soil, the tap root and deeper roots have more influence on overturning resistance in sandy soil compared with clayey soil (Fourcaud et al. 2008). Wind loading appears to result in increased growth of lateral roots at the expense of the tap root. Development of the lateral root system may therefore ensure better anchorage of young trees subjected to wind loading (Tamasi et al. 2005).

Root branching shortens the root plate lever arm and makes tipping easier. The roots of nearly all trees in urban areas have been severed during transplanting, which creates branching at the cut end and smaller regenerated roots. This branching may shorten the root plate fulcrum on the leeward side and reduce the diameter of the roots at the perimeter of the root plate, with the possible effect of rendering urban trees less stable than their forest counterparts with less-branched, larger roots. However, no direct research on urban trees is available.

\section{ROOT INJURY}

\section{Consequences of Root Severing}

Analysis of published data on root spread of trees concluded that the radius of the root system is approximately equal to tree height (Day et al. 2010), which is often greater than the radius of the branches (drip line). Given the close proximity of trees to structures, pavements, and utilities in most urban and suburban landscapes, tree roots can be easily injured by soil excavation.

Root loss from severing can be considered temporary when roots are able to regenerate and eventually replace roots that were lost. If the root space is permanently lost (e.g., resulting from construction of a structure or pavement in the root zone), then the root system will not be able to replace itself, and stress and stability concerns may never be overcome.

Root loss from trenching can affect both tree health and stability. Trenching through the root zone of parkway trees was considered to be responsible for substantial tree dieback and decline over the following 12 years, and was the basis for development of auguring specifications in common use (Morell 1984). While generally accepted, the little research available has not been completely supportive.

When trenches were dug for installation of new utilities 0.5 to $3.3 \mathrm{~m}$ from hackberry (Celtis occidentalis), sweetgum (Liquidambar styraciflua), sugar maple (Acer saccharum), and honeylocust (Gleditsia triacanthos), only on hackberry, where the trench was only $0.5 \mathrm{~m}$ from the trunk (approximately 1.5 times the trunk diameter), was growth-reduced for all four growing seasons monitored following trenching. The trenching did not predispose the trees to readily evident disease or insect infestations (Miller and Neely 1993). If the trench was three times the trunk diameter away from the trunk, or more, no consistent growth reduction was measured. No growth reduction or dieback was reported when pin oak (Quercus palustris) trees were trenched on one or two sides at a distance of three times the trunk diameter. However, moderate dieback was noted on trees that were trenched on three sides (Watson 1998). Street or sidewalk construction at a distance of five to seven times the trunk diameter from the tree resulted in only a $4 \%$ increase in mortality and a $5 \%$ decrease in condition rating (Hauer et al. 1994).

Root loss reduces the capacity of the root system to absorb water, most of which is transpired through the leaves. Compensatory pruning along with severe trenching reduced dieback from stress but was most beneficial after the most severe root loss (Watson 1998). These trees did not receive any irrigation or special care, which could possibly have reduced dieback development even without pruning.

Hamilton (1988) suggested that some species may be more prone to uprooting after root pruning, based on observation. Stability of trees after the roots have been severed is a concern that has not been fully addressed by research. When trenches were cut alongside trees, tree anchorage was compromised by trenches only when closer than 2.5 times the diameter of the trunk on the tension side (Bader 2000; Smiley 2008b; Ghani et al. 2009). The surprisingly high anchorage of the trees with such severe root loss was thought to be because rooting depth close to the trunk was a major component of anchorage. Cutting roots on both sides of the tree reduced the force required to cause tree failure by two-thirds when trees were trenched simultaneously at five times the trunk diameter on the tension side and about half that distance on the compression side (approximate location of the root plate hinge point) (O'Sullivan and Ritchie 1993). Trees with asymmetrical or restricted root systems may be less stable after root severing.

These studies suggest that vigorous trees less than $30 \mathrm{~cm}$ diameter may be able to tolerate roots being 
severed on one side as close as three times the trunk diameter without a major loss in stability or crown decline. Larger trees, such as those on which the specifications were based, may be less tolerant. As surprising as it might seem that root severing did not kill any trees or cause severe dieback in these studies, consider that when roots are cut to form a root ball to transplant a tree, roots are cut on all sides at a distance of three to five times the diameter of the trunk (Anonymous 2004; Anonymous 2010). The trees are stressed, but even very large trees recover if cared for properly. Comparison of trenched trees in the established landscape to transplanted trees may be fairly realistic (Hamilton 1988).

\section{Root Decay}

Principles of Compartmentalization of Decay in Trees (CODIT, Shigo 1977) apply to roots as well as stems, although roots have not been studied as extensively (Shigo 1972; Shigo 1979a; Tippett and Shigo 1980; Tippett and Shigo 1981; White and Kile 1993; Robinson and Morrison 2001). Because root injuries are common and injuries serve as infection courts for root-rotting organisms (Tippett et al. 1982), roots have evolved to be strong compartmentalizers (Shigo 1986).

Average values of longitudinal extension of decay columns in roots of Sitka spruce (Picea sitchensis), white fir (Abies concolor), and Norway spruce (Picea abies) after artificial inoculation have been reported from 10 to $53 \mathrm{~cm}$ per year, (Morrison and Redfern 1994; Garbelotto et al. 1997; Piri 1998). Decay introduced experimentally through root wounds within a meter of the trunk can extend into the trunk (Redmond 1957; Garbelotto et al. 1997).

In contrast, the natural infection of landscape tree roots 3 to $22 \mathrm{~cm}$ in diameter after severing has not led to extensive decay development. Five to seven years after severing, decay extended no more than $10 \mathrm{~cm}$ from the severed end of roots of 7-year-old sweetgum (Liquidambar orientalis $\times$ L. styraciflua) and plane hybrids (Platanus occidentalis $\times$ P. orientalis) (Santamour 1985), or 40-year-old honeylocust (Gleditsia triacanthos var. inermis), pin oak (Quercus palustris), tulip-tree (Liriodendron tulipifera), and green ash (Fraxinus pennsylvanica) trees (Watson 2008). Trunk wood decay was observed only when the root cambium had died back to, or above, the soil surface and may have been the result of trunk injury (cambial death) rather than the root wounding (Santamour 1985). Although the number of research studies is limited, these results suggest that decay development as a result of severing roots is not an immediate threat to the health or stability of a tree.

Santamour (1985) also reported differences between species in their ability to resist trunk decay and discoloration after root severance. Four years after severing roots within $0.5 \mathrm{~m}$ of the trunk, there was no discoloration or decay in trunk tissues in red maples (Acer rubrum), and $6 \mathrm{~cm}$ maximum in the roots. Discoloration and decay was present in trunk tissues of 2 of 10 black oaks (Quercus velutina) and 4 of 10 white oaks (Q. alba) after similar root severance.

Root size and proximity to the trunk has been reported to affect decay development rate. Root decay increased as root size increased on hardwoods (Whitney 1967; Santamour 1985; Balder et al. 1995; Balder 1999) and conifers (Piri 1998; Tian and Ostrofsky 2007). Injury to roots close to the trunk resulted in more extensive decay on hardwoods (Shigo 1979b; Balder et al. 1995; Balder 1999). Other studies do not support these conclusions (Shigo 1991; Watson 2008). Injury of roots in the dormant season may lead to poorer compartmentalization and increased decay development, but reports are inconsistent (Santamour 1985; Balder et al. 1995; Balder 1999).

Stressing and limiting the development of roots, particularly constriction of root diameter growth, as results from certain root defects, predispose the roots to Armillaria infection (Livingston 1990). The increased success of infection by Armillaria sp. as a result of root severance appears to be associated with changes in the nutrient status of the roots after they have been damaged, rather than simply an increase in sites for penetration (Popoola and Fox 1996).

Trees that fail due to root decay under nonstormy conditions often have extensive decay in the root flare (roots forming the curvature between vertical trunk and the angled structural roots, also known as buttress roots). Decay can develop on the lower side of major flare roots, where it can remain undetected. Drilling is recommended to determine the amount of sound wood. Major flare roots are considered significantly decayed if the thickness of the sound wood on the root is less than 0.15 times the tree diameter (Fraedrich and Smiley 2002). Thermography can be effective in 
approximating the decayed areas of the root collar (Cellerino and Nicolotti 1998; Catena 2003).

\section{Locating Roots}

Locating roots prior to construction to avoid damaging them is time-consuming and expensive if done with hand digging. Introduction of air excavation tools has made the task considerably more efficient (Nadezhdina and Cermak 2003). Non-destructive, ground-penetrating radar can be used to map larger roots. Roots $1.0 \mathrm{~cm}$ diameter and larger, and as deep as $2 \mathrm{~m}$, can be detected (Hruska et al. 1999; Cermak et al. 2000; Butnor et al. 2001; Butnor et al. 2003; Nadezhdina and Cermak 2003; Barton and Montagu 2004). Vertical roots and roots with less than $20 \%$ water content could not be detected by ground-penetrating radar (Stokes et al. 2002; Hirano et al. 2009). Two roots located closely together cannot be individually distinguished (Hirano et al. 2009; Bassuk et al. 2011).

Resolution of roots may be best in sandy, welldrained soils, whereas soils with high soil water and clay contents may seriously degrade resolution and observation depth (Butnor et al. 2001). Interference from other objects present in the soil was sometimes found to be a problem in early ground-penetrating radar studies (Cellerino and Nicolotti 1998; Hruska et al. 1999). Groundpenetrating radar was effective in structural soil, which is $80 \%$ stone (Bassuk et al. 2011). Roots could be mapped under concrete and asphalt (Nadezhdina and Cermak 2003; Bassuk et al. 2011). Development of software to reconstruct 3D images of root system architecture from raw data may still need improvement (Stokes et al. 2002).

\section{Root Regeneration}

Root severing can increase the rate of root growth on one-year-old seedlings or rooted cuttings, but the more rapid root production merely compensates for the roots removed (Abod and Webster 1990). The potential for water uptake is proportional to the number of new roots produced (Carlson 1986).

When woody roots are severed, numerous new roots are initiated at, or just behind, the cut (Wilcox 1955; Carlson 1974; Watson and Himelick 1982a; Gilman et al. 2010). However, a portion of regenerated roots can originate from at least 10 $\mathrm{cm}$ behind the cut, depending on species (Gilman and Yeager 1988). The ability of damaged roots to form new roots decreased with increasing diameter (Balder et al. 1995; Balder 1999). When a root is severed, new roots that formed nearest to the cut surface will elongate in the same direction as the original root. New roots forming slightly behind the cut surface tend to grow at more perpendicular angles to the original root (Horsley 1971).

Initiation of new roots from severed palm roots varies with species and distance from the base of the trunk (Broschat and Donselman 1984). Less than one percent of all cut cabbage palm (Sabal palmetto) roots regenerated root tips, whereas coconut palms (Cocos nucifera) regenerated root tips about $50 \%$ of the time regardless of root stub length. For other species of palms, such as queen palm (Syagrus romanzoffiana), royal palm (Roystonea regia), Mexican fan palm (Washingtonia robusta), and Senegal date palm (Phoenix reclinata) the percentage of roots surviving increases with stub length (Broschat and Donselman 1984; Broschat and Donselman 1990a). Cutting palm roots at least $30 \mathrm{~cm}$ from the trunk will ensure better survival of existing roots (Broschat and Donselman 1990a).

Auxins are commonly used to promote rooting in stem cuttings and can increase the number of new roots initiated near the cut ends of roots. Indole-3-butyric acid (IBA), indole-3-acetic acid and naphthaleneacetic acid applied to roots resulted in increased root initiation (Gossard 1942; Verzilov 1970; Lumis 1982; Magley and Struve 1983; Prager and Lumis 1983; Struve and Moser 1984; Fuchs 1986; Watson 1987; Al-Mana and Beattie 1996; Percival and Gerritsen 1998; Percival and Barnes 2004), but may reduce root elongation (Struve and Moser 1984; Percival and Barnes 2004). Addition of 5\% sucrose to the auxin solution enhanced the results (Fuchs 1986). Verzilov (1970) reported increased root growth into the third season after application but was unsure if it was a residual effect of the auxin application or resulted from greater tree vigor after the initial increase in root growth. IBA treatment did not increase root initiation of palms (Broschat and Donselman 1990b).

The rate of new root initiation is affected by the environment. At near-optimum soil temperatures, new root growth was detected in 4 to 43 
days depending on species (Howland and Griffith 1961; Arnold and Struve 1989). Intact root tips began to elongate before new roots were initiated (Arnold and Struve 1989). Total new root length was positively correlated with soil temperature with significantly more new root growth at $20^{\circ} \mathrm{C}$ (Andersen et al. 1986). Tree fine-root growth was slowed by approximately half when soil temperatures dropped from $20^{\circ} \mathrm{C}$ to $10^{\circ} \mathrm{C}$ (Tyron and Chapin 1983). When roots are severed late in autumn, after soils have cooled, substantial new root growth may not occur until the soils have warmed again in the spring. In warmer regions, active root growth may continue all winter. Plants that were slightly drought-stressed prior to severing roots had greater root regeneration (Abod and Sandi 1983), but decreased soil moisture after severing significantly reduced root regeneration (Witherspoon and Lumis 1986). Plants supplied with adequate (non-deficient) nutrients before transplanting had a high capacity to regenerate roots following root severing (Abod 1990).

Annual root extension depends on species and annual soil temperature regime. In the upper Midwestern United States (USDA Hardiness Zone 5), with its moderate summers and frozen soils in winter, roots grow at an average annual rate of approximately $50 \mathrm{~cm}$ (Watson 1985; Watson 2004). In one season under nursery conditions in Hardiness Zone 6, red oak (Quercus rubra) roots grew 53-61 cm (Starbuck et al. 2005) and birch (Betula pendula) roots grew $89 \mathrm{~cm}$ (Solfjeld and Pedersen 2006). In the subtropical climate of north central Florida (Hardiness Zone 9), where the growing season is nearly year-round, annual root growth is up to $2 \mathrm{~m}$ or more for some oak (Quercus) and citrus species that have been studied (Castle 1983; Gilman 1990; Gilman and Beeson 1996). As the roots continue to increase in length, fine roots continue to increase in density for up to five years (Hutchings et al. 2006).

Root growth for some species will be higher or lower than average figures. For example, black maple (Acer nigrum) roots grew $39 \mathrm{~cm}$ in a season in the midwestern United States, which is near the expected average. Under the same conditions, green ash (Fraxinus pennsylvanica) grew nearly twice as much, 67 $\mathrm{cm}$ (Watson 2004). In general, it may require many years to replace the roots lost when they are severed.

\section{Fine-Root Desiccation}

There is sometimes concern that fine roots subject to drying by excavation will be damaged. Desiccation of little-leaf linden (Tilia cordata), green ash (Fraxinus pennsylvanica), and sugar maple (Acer saccharum) fine roots had no effect on root regeneration (Witherspoon and Lumis 1986; Watson 2009), though moisture content was reduced by as much as $80 \%$ (Watson 2009). In contrast, root growth of wild cherry (Prunus avium) and cherry plum (P. cerasifera), and of noble fir (Abies procera) seedlings, was reduced after desiccation treatment (Symeonidou and Buckley 1997; Bronnum 2005). Susceptibility of fine roots to damage from desiccation may be species dependent.

\section{ALTERATION OF ROOT STRUCTURE} Root structure and tree growth rate are closely related. For conifers (Picea sp., Abies sp., Pinus taeda) and hardwoods (Quercus sp., Liquidambar styraciflua, Juglans nigra) studied, when one-yearold seedlings are sorted by root morphology, individuals with a high number of laterals consistently have greater growth after planting (Kormanik 1986; Ruehle and Kormanik 1986; Kormanik 1988; Kormanik et al. 1989; Schultz and Thompson 1997; Kormanik et al. 1998; Gilman 1990; Ponder 2000). Little information is available on how long this increased growth persists, but large forest trees that have out-competed their weaker neighbors over a lifetime typically have many visible flare roots.

\section{Structural Root Depth}

The large woody roots giving characteristic form to the root system are commonly referred to as structural roots (Sutton and Tinus 1983). These roots can be too deep for many reasons. Roots of young trees can be too deep because nursery production systems can increase structural root depth. Pruning the primary (tap) root of seedlings early in the production of field-grown nursery stock produces adventitious roots at the cut end of the primary root that grow rapidly (Johnson et al. 1984; Harris et al. 2001; Hewitt and Watson 2009). Up to $60 \%$ of the natural lateral roots that would normally develop into flare roots located above the regenerated roots may be lost (Hewitt and Watson 2009). The vigorously growing adventitious roots at the cut end, 
and loss of natural lateral roots above them, often replace the natural root flare (swelling where roots join the trunk also known as the trunk flare) with an "adventitious root flare" deeper in the soil. The depth of the adventitious root flare is determined by the length of the primary root after pruning (root shank). Even if the tree is planted at the original depth with the graft union visible aboveground, the adventitious root flare can be $30 \mathrm{~cm}$ or more below the soil surface. Other practices, such as burying the graft union below the soil surface and certain cultivation practices, can also contribute to root depth. Young trees can be more susceptible to being blown over by high winds when depth to the first root is excessive (Lyons et al. 1982).

The structural roots can also be too deep in container-grown nursery stock if trees are not planted carefully at each repotting. A dense mat of roots can fill the soil above the woody roots that form the root flare (Fare 2006; Gilman and Harchick 2008; Gilman et al. 2010b), and make it impossible to plant the woody roots at the correct depth without cutting away a substantial portion of the roots in the ball.

Though trees may grow well enough in the well-drained substrate of the container or highquality soil of the nursery field, they may struggle to survive when planted on difficult urban sites with heavy soils and poor drainage (Switzer 1960; McClure 1991; Day and Harris 2008). The consequences may not be seen immediately. Regenerated roots can grow back to the surface (Day and Harris 2008), but the root collar will always be too deep. Dramatic improvements in tree condition have been attributed to root collar excavation in practice (Smiley 2006). In the only published research study, street trees failed to show any influence of root collar excavation on tree growth over a four-year period (Rathjens et al. 2009).

Root systems of established trees can become deeper when fill soil is added over them. Research has not been able to consistently show detrimental effects on trees, though reports from practice attribute poor performance and Armillaria and Phytophthora infections to deep roots and soil against the trunk (Smiley 2006). After three years, there was no consistent effect of $20 \mathrm{~cm}$ of C horizon fill on overall root density, growth, or soil respiration. Fill did disrupt normal soil moisture patterns (Day et al. 2001). After approximately ten years, the fill still had no effect on trunk diameter growth. Bark of some oak trees appeared to be decaying, but bark biopsies revealed only saprophytic fungi (Day et al. 2006). A "collar rot" caused by a Phytophthora sp. and a "basal canker" caused by Fusarium spp. were associated with buttress roots of planted maples that were deeper than roots of natural, woodland maples (Drilias et al. 1982).

Installation of subterranean piping systems or core venting systems to counter the adverse impact of fills is sometimes recommended (Harris et al. 1999). Studies of aeration pipes installed prior to addition of fill have been inconclusive. With or without pavement-like surface cover, conditions under fill were not severe enough for any "improved" effect to be measured from the use of an aeration system. Greater trunk growth in plots with aeration pipes was attributed to increased soil moisture in the plot with aeration pipes (MacDonald et al. 2004; Townsend et al. 1997). These results underscore the need for further quantitative studies of conditions created by various fill and paving procedures to better ascertain the usefulness of elaborate and expensive aeration systems. Other factors associated with raising the grade, such as soil trafficking and root severance, may be responsible for much of the tree decline attributed to fill.

A layer of crushed rock over existing soil before filling with clay soil increased oxygen (percent) and reduced carbon dioxide in the soil beneath it compared to a comparable area where no crushed rock was used before clay fill was placed over the soil surface (Yelenosky 1964).

\section{Circling Roots}

Growing trees in nursery containers alters natural root structure (Halter et al. 1993). Reports are rare of adventitious roots developing above the circling, kinked, or twisted form found within the container root ball after planting (Gilman and Kane 1990).

Circling roots on the surface of the container root ball are widely recognized as a defect and it is common practice to disrupt these by making several vertical cuts, or "slashes," on the outside of the root ball before planting (Ellyard 1984; Blessing and Dana 1987; Arnold 1996; Gilman et al. 1996). Methods that disrupt circling roots do not eliminate descending, ascending, and kinked roots. Con- 
tainers designed to prevent circling often direct roots contacting the wall down to the bottom or up to the surface. Root deformities often become a permanent part of the root system (Grene 1978).

Root ball "shaving" is cutting off the outer surface of the root ball to remove all roots on the root ball surface. It results in a root system with roots growing more radially from the trunk (Burdett 1981; Gilman et al. 2010). Root growth after planting trees from containers without shaving was one-quarter of that of field-grown trees and resulted in reduced tree stability (Gilman and Masters 2010). Growing plants in $\mathrm{CuCO}_{3}$-treated containers resulted in the reduced defects after planting in the landscape (Burdett 1978; Arnold and Struve 1989; Arnold 1996).

\section{Girdling Roots}

Girdling roots have a different origin than circling roots caused by production containers and can be a significant problem for at least some species of trees planted as field-grown stock. Norway maples (Acer platanoides) frequently had severely girdling roots as mature trees (Watson et al. 1990; Wells et al. 2006). All 50-year-old Norway maples (Acer platanoides) had one to nine girdling roots. There was no grafting between girdling roots and trunks (Tate 1980). Girdling roots and potentially girdling roots were more common on sugar maple (Acer saccharum) and red maple (Acer rubrum) than on green ash (Fraxinus pennsylvanica), honeylocust (Gleditsia triacanthos), littleleaf linden (Tilia cordata), and Yoshino cherry (Prunus $\times$ yedoensis) trees, 2 to 10 years after planting.

The majority of the girdling roots can be either small, existing laterals when transplanted, or new laterals initiated during the first year after transplanting. Lateral roots at perpendicular angles, close to the base of the trunk, are naturally positioned to develop into girdling roots. Growth of these lateral roots is often slow while the root terminal is intact, but can be stimulated when the terminal is severed as the tree is dug from the nursery. Further evidence that girdling roots result from transplanting is provided by the low incidence of girdling roots found in nature (Watson et al. 1990).

Girdling roots have been associated with excessive soil over the root system (d'Ambrosio 1990; Giblin et al. 2005; Wells et al. 2006), though not always (Watson et al. 1990). One report hypothesized through observation that girdling roots are associ- ated with low dense crowns creating cool and moist conditions at the base of the tree (d'Ambrosio 1990).

Cross-sectional area of vessels in stem xylem affected by the girdle was only $10 \%$ that of unaffected wood. Rays in stem wood were skewed and contained few pits. Bark on girdled stems was compressed from a normal thickness. The offending roots sustained slight compression of cells where in contact with the stem and appeared to remain functional. Thus, girdling roots apparently cause tree decline by reducing stem conductivity and radial communication between tissues (Hudler and Beale 1981).

Girdling roots do not always cause rapid decline or death of trees. Aboveground decline symptoms of girdling roots include gradual shortening of terminal growth, small leaves, early autumn color, dieback of branches in sections of the canopy, and partial or total absence of a root flare (Gouin 1983; Holmes 1984). A survey of 416 urban Norway maples (Acer platanoides) found that although 336 had girdling roots, most girdling was minor and did not lead to visible decline of the trees (Tate 1981). Red (Acer rubrum) and sugar maples (Acer saccharum) artificially girdled with angle iron to simulate a girdling root on one side, remained alive for seven to eight years, but Norway maples engulfed the girdling devices and were alive after 17 years (Holmes 1984).

Treatments consisting of cutting girdling roots, fertilizing, and pruning foliage were evaluated after two years and did not alleviate aboveground symptoms (Tate 1980). Removal of potential girdling roots resulted in a detrimental effect on twig extension (Rathjens et al. 2009). Removal of girdling roots as an early corrective treatment on young Norway maple trees did not eliminate them. Multiple roots reformed from the wound site where a single girdling root had been removed. Despite this lack of validation by research, girdling root removal continues to be a common practice. The best hope for eliminating girdling root problems may be to develop root stock from trees without girdling roots (Watson and Clark 1993).

Girdling by wires of the wire baskets used to support root balls during shipping and handling is a similar situation. Studies with wires girdling stems of young trees showed no detrimental effect of girdling (Goodwin and Lumis 1992). Examination of roots contacting wires 11 years after planting found that root tissues reunited after closing 
around the wire and there was complete union of vascular tissue beyond the wire (Lumis and Struger 1988). The small diameter of the wires may pose less of a threat than larger roots similarly positioned.

\section{Root Grafts}

Root grafting can be beneficial or detrimental to trees, depending on the circumstances. When root grafts between individuals of the same species occur, the grafts allow passage of solutes through the connecting xylem (Graham and Bormann 1966; Jane 1969). Girdled trees with no transport of carbohydrates from the crown to the root system can survive for years if their roots are supported through grafts to roots of neighboring trees (Stone 1974).

Root grafts among groups of elms were considered responsible for more than $50 \%$ of Dutch elm disease disease transmission when the disease was at its peak in U.S. cities (Cuthbert et al. 1975). Oak wilt is also commonly transmitted through root grafts (Gibbs and French 1980; Appel 1994). In both situations, disrupting root grafts is an important method of disease control. Both mechanical and chemical methods of severing roots have a long history (Himelick and Fox 1961; Neely and Himelick 1966), with more recent variations tested (Wilson and Lester 2002).

\section{INFRASTRUCTURE-ROOT CONFLICTS}

\section{Pavement Conflicts}

When pavements are laid on a compacted soil base, roots often grow in the gap between the pavement and the compacted soil under it. Moisture is high because the pavement prevents evaporation, and condensation can form beneath the pavement as it cools (Kopinga 1994a; Kopinga 1994b; Wagar and Franklin 1994). Aeration can be adequate, especially under narrow pedestrian sidewalks (Kopinga 1994a; D’Amato 2002a). Roots enlarge and can eventually lift and crack the pavement. Species that have a small number larger roots could cause considerably more damage than if the same biomass were allocated between larger numbers of smaller roots (Nicoll and Coutts 1997).

Potential for conflicts between trees and pavement is high when one or more of the following factors are present: tree species that are large at maturity, fast growing trees, shallow rooting habit, trees planted in restricted soil volumes, shallow topsoil (hardpan underneath topsoil), limited or no base materials underneath the sidewalk, shallow irrigation, distances between the tree and sidewalk of less than two to three meters, or trees greater than 15 to 20 years old (Wong et al. 1988; Randrup et al. 2003). Large trees in restricted planting spaces is most commonly associated with pavement damage (Barker 1983; Wagar and Barker 1983; Wong et al. 1988; Francis et al. 1996; Achinelli et al. 1997; McPherson 2000; D'Amato et al. 2002b; Reichwein 2002; Reichwein 2003).

Research has challenged the common assumption that sidewalk pavement cracks near roots are always caused by the roots. Sidewalk damage can result from soil conditions and age of pavement as well as from tree roots. Older sidewalks failed more often. Sidewalks did not fail at higher rates where trees were present (Sydnor et al. 2000). With no roots present, $61 \%$ of all pavement expansion joints were also cracked (D'Amato et al. 2002a). Roots were more likely to be found under a cracked expansion joint in the sidewalk than under an uncracked joint, but the cracks may actually be contributing to roots growing under sidewalk pavements. Sidewalks that fail may allow more root growth beneath the cracks due to increased oxygen in the soil (Sydnor et al. 2000; D’Amato et al. 2002a).

Barriers are sometimes installed to prevent root growth under pavement. Barriers have been constructed from plastic, metal screening, and geotextile impregnated with herbicide. Most are effective at blocking roots between the surface and the bottom of the barrier if installed correctly. Differences in products have sometimes been reported in the first few years, but may not persist with time (Smiley et al. 2009).

Installation of root barriers reduces the number and diameter of roots and causes them to grow deeper for a limited distance on the far side. This has been reported consistently, and in both poorly drained (Wagar 1985) and well-drained and wellaerated soils (Gilman 1996; Costello et al. 1997; Nicoll and Coutts 1998; Peper 1998; Peper and Mori 1999; Smiley 2005; Pittenger and Hodel 2009; Smiley et al. 2009). After they grow under the barrier, roots do grow back toward the surface within a short distance from the barrier, but may remain deeper long enough to reduce pavement damage. 
The effectiveness of barriers may not be permanent, since pavement damage by 30 -year-old sweet cherry (Prunus avium) roots was associated with large roots as deep as $40 \mathrm{~cm}$ below the pavement (Nicoll and Armstrong 1997; Nicoll and Armstrong 1998).

Depth and installation of the barrier is important. A $45 \mathrm{~cm}$ deep barrier reduced roots under the pavement (Smiley 2008a) while a $30 \mathrm{~cm}$ barrier of similar design did not (Gilman 2006). Barriers need to be installed with the uppermost edge above grade. If roots are able to grow over the top of the barrier because of incorrect installation, deterioration of the exposed barrier material, or mulching over the barrier, can result in significant damage to pavements (Smiley 2008a; Tworkoski et al. 1996).

Barriers can reduce overall root development of trees (Wagar and Barker 1993; Barker 1995a; Gilman 1996; Smiley et al. 2009), but in most studies, no effect on trunk diameter growth was reported (Barker 1995a; Barker 1995b; Tworkoski et al. 1996; Costello et al. 1997; Peper 1998; Peper and Mori 1999; Gilman 2006; Smiley 2008a).

There is no evidence that root barriers will decrease stability. Slightly more force was required to pull over trees within root barriers. The increased stability was attributed to deeper roots (Smiley et al. 2000). The situation may be different if roots are not able to grow under the barrier, such as on sites with very poor soil aeration or very deep barriers. In such a situation, the limited root system on one or more sides could result in increased instability.

Other alternatives to root barriers have proven to be effective in preventing roots from growing beneath pavements and causing cracking and lifting. Extruded polystyrene foam 10 $\mathrm{cm}$ thick installed directly under poured concrete forced roots to grow under the foam. The expanding roots crushed the foam instead of heaving the pavement (Smiley 2008a).

When pavements were laid on a base of coarse gravel or brick rubble, the coarse material was apparently not a suitable environment for root growth between the stones, and the roots grew in the soil underneath it. Thicknesses of $15 \mathrm{~cm}$ and $30 \mathrm{~cm}$ were somewhat more effective than $10 \mathrm{~cm}$ (Kopinga 1994a; Gilman 2006; Smiley 2008a).

A $10 \mathrm{~cm}$ thick layer of structural soil beneath the pavement is not the intended use of structural soil, but has been used in place of gravel in prac- tice (Smiley 2008a). Whereas the use of gravel discouraged root growth, a similar $10 \mathrm{~cm}$ deep layer of structural soil allowed vigorous root growth in the soil between the coarse stones, as it is designed to do. Roots in the stone layer resulted in extensive pavement cracking and lifting. When structural soils are used with a minimum depth of $60 \mathrm{~cm}$, or a preferred depth of $90 \mathrm{~cm}$, roots grew to the full depth of the structural soil and were not found exclusively at the surface (Grabosky et. al. 2001).

Certain root barrier products that are impregnated with herbicides to reduce root growth can be effective as root barriers, but raise concerns that mycorrhizae could be affected. Sweetgum (Liquidambar styraciflua, endomycorrhizal) and pin oak (Quercus palustris, ectomycorrhizal) root mycorrhizae collected from within $1 \mathrm{~cm}$ of a chemically impregnated barrier were unaffected in the only reported study (Jacobs et al. 2000). (For an extensive review of root barrier research, see Morgenroth 2008.)

Just as disease resistance is the preferred way to control a tree disease, developing trees with deeper root systems would be the best way to reduce pavement damage. Research has shown that root systems of certain tree species that often cause sidewalk damage [e.g., shamel ash (Fraxinus uhdei), zelkova (Zelkova serrata), Chinese pistache (Pistacia chinensis)] can be selected for deep rooting patterns. Unfortunately, when these trees were propagated by rooting cuttings; the propagated trees did not exhibit the same deep-rooting characteristic (Burger and Prager 2008).

\section{Sewer Pipe Intrusion}

Tree root intrusion into sewer systems can be a substantial problem. Tree roots rarely damage pipes, but Mattheck and Bethge (2000) hypothesize that when a tree root encircles a pipe, wind loading may result in enough movement to break the pipe, especially when this occurs near material defects.

Roots can enter pipes in breaks and loose joints and then proliferate rapidly once inside the moist, nutrient-rich environment. Older pipes have more root intrusions because of age and materials used. Clay and concrete pipes without rubber gaskets in the joints resist root intrusion the least. The most intrusions have been into the smaller dimension pipes, $22.5-40 \mathrm{~cm}$, possibly because the larger pipes are usually deeper in the soil and the roots may not 
reach them as easily. Sandy soils are more easily penetrated by roots reaching pipes. In poor growing conditions, the roots seek their way into the pipes relatively quickly, while in good growing conditions the process is considerably slower. In general terms, full-grown trees that have a large crown volume and thus a high requirement for water during the growing season have the greatest potential to cause large-scale damage to sewage systems by root intrusion. Certain tree species, such as poplar (Populus), willow (Salix), Melaleuca (Melaleuca), and Eucalyptus (Eucalyptus) are more likely to cause root intrusion. Tree size and proximity to the sewer pipe are also factors (Stål 1992; Lidstrom 1994; Rolf and Stål 1994; Stål 1995; Pohls et al. 2004; Ridgers et al. 2006).

Herbicides have been used to control root growth in sewer pipes. Metam-sodium and dichlobenil in combination is the most common. Metam-sodium is non-systemic and does not move throughout the root system, killing the whole plant. Dichlobenil is used with metam-sodium because it is an effective growth inhibitor. Air-aqueous foam is more effective than an aqueous mixture. The amount of chemical used in the foam application is small. Rapid breakdown of the metam-sodium and dilution of the product in the wastewater minimize environmental impacts, but use is still restricted in many areas (Ahrens et al. 1970; Leonard and Townley 1971; Leonard et al. 1974; Prasad and Moody 1974; Pohls et al. 2004).

Strategies to combat root intrusion are limited. Tree roots are less likely to grow into sewer pipes if planted $6 \mathrm{~m}$ or more from existing pipes. Slower-growing species with less aggressive root systems are best. Pipe construction can reduce intrusion by using longer pipe segments with fewer joints and proper installation (Rolf et al. 1995; Stål 1998; Randrup 2000).

\section{Foundation Damage}

Tree roots have been associated with interference with building foundations but rarely cause direct damage. Force from roots increasing in diameter is small, and damage only occurs to lightly loaded structures (Day 1991; Macleod and Cram 1996).

Roots in the vicinity of shallow foundations on soils with a high shrink-swell capacity can contribute to soil moisture depletion during drought, causing the soil to shrink and the building foundation to settle and crack (Day 1991). Records in England show that the incidence of failure of foundations on shrinkable clay soils is greater by a factor of ten than on other soils (Pryke 1979).

Tree genera vary in the amount their root systems can spread and contribute to building subsidence. [Roots cannot be reliably identified to species through anatomical features (Cutler et al. 1987).] The distance between damaged foundations and the tree with roots contributing to the damage was recorded for over 11,000 trees in the Kew Tree Root Survey. The average distance at which foundation damage was recorded varied from $2.5 \mathrm{~m}$ for cypress (Cupressus) to $11 \mathrm{~m}$ for poplar (Populus) with damage from most species occurring between $5 \mathrm{~m}$ and $7 \mathrm{~m}$ (Cutler and Richardson 1989). Depth of water extraction by roots may be restricted by soil conditions. Sharp changes in water and air permeability retarded rooting and water extraction beyond the upper $0.5 \mathrm{~m}$ of soil (Misra and Sands 1993). Species such as ash (Fraxinus), with relatively poor stomatal control of water loss, may accelerate soil drying, and therefore shrinkage (Stewart and Sands 1996).

Coutts (1979) suggests that since roots will grow where conditions are most favorable, and urban landscapes often have pavements and other features that restrict root growth in areas away from buildings, the most favorable soil may be between the tree and the building.

Control of roots with barriers is not considered an acceptable solution. Roots can grow under or over the barrier if not properly installed (as previously stated), or through cracks that may develop over time (Marshall et al. 1997). When roots are deflected laterally, there is a tendency to resume the original direction of growth once past the barrier (Wilson 1967), unless the barrier is long (Riedacker 1978).

Pruning is ineffective in controlling water use. Crown thinning did not reduce total tree water use or soil drying. A crown reduction of over $70 \%$ by volume affected water use for only a single season (Hipps 2004). The only way to ensure that there will not be a recurrence of the subsidence event after repair is to remove the tree (O'Callaghan and Kelly 2005).

Two solutions to the problem are to plant the tree well away from the structure or to use deepened perimeter footings to restrict roots from gaining access beneath the foundation (Day 1991). A combination of these is employed in the British National House Building Council guidelines, 
which provide recommendations based on shrinkability of the soils, the depth of the foundation, and the water demand and mature height of the tree. On a highly shrinkable soil, if a high water demand tree is located a distance equal to its height away from the foundation, the foundation should be $1.5 \mathrm{~m}$ deep. At half of that distance, a $2.5 \mathrm{~m}$ deep foundation is recommended (Biddle 1998).

\section{ROOT SPACE REQUIREMENTS}

When trees are planted in paved areas, the limited root space available in planting pits will ultimately limit the size and longevity of the tree (Fluckiger and Braun 1999). Average tree life expectancy in a sidewalk pit can be as little as ten years (Kopinga 1991; Nowak et al. 2004). Root restriction can reduce shoot elongation and decrease root dry weight:leaf area ratio. Imbalanced root:shoot ratios caused the development of internal water stress and plant senescence (Tschaplinski and Blake 1985; Vrecenak et al. 1989; Rieger and Marra 1994; Ismail and Noor 1996).

Crown spread and trunk diameter of trees growing in parking lots is reduced as surface area of nonpaved surfaces is reduced (Grabosky and Gilman 2004). Ninety-six percent of parking lot trees with at least $28 \mathrm{~m}^{3}$ of soil were in good condition, compared to only $60 \%$ in less than $14 \mathrm{~m}^{3}$ of soil. However, over $80 \%$ of the trees had been planted in the last 12 years (Kent et al. 2006), and condition of trees is likely to deteriorate as the trees grow and reach the limits of even the most generous root space.

\section{Soil Volume and Quality}

Variables to consider when determining how much root space is needed includes the quality of the soil present (water and nutrient storage capacity), how much evaporation and transpiration is expected, and how often the tree will receive rainfall or irrigation. As a general guideline for temperate climates, if above- and belowground environmental extremes are not severe, the root space recommendations vary from 0.15 to $0.7 \mathrm{~m}^{3}$ of soil for each square meter of crown projection area of the expected mature size of the tree (Kopinga 1985; Lindsey and Bassuk 1991; Lindsey and Bassuk 1992; Urban 1992; Urban 2008). Similar estimates have not been developed for arid and semi-arid climates.

A computer model has been developed that uses climatological data to estimate the soil vol- ume necessary to provide moisture in growing conditions likely to be encountered for an area. The example used is New York City, New York, U.S., with a $6 \mathrm{~m}$ crown diameter tree and $17 \mathrm{~m}^{3}$ of soil, as recommended by Lindsey and Bassuk (1991). The tree, without irrigation, would face a water deficit every other year. With $27.4 \mathrm{~m}^{3}$ of soil the tree would face a deficit only once in 10 years, but with only $4.3 \mathrm{~m}^{3}$ of root space soil, the tree would need irrigation every fifth day to face a deficit only once in 10 years (DeGaetano 2000). Using a different method, Blunt (2008) calculated that under UK weather conditions, a mature tree (size and species not specified) would require at least $50 \mathrm{~m}^{3}$ of high-quality soil with soil moisture recharged by rainfall or irrigation ten times during the growing season to avoid drought stress.

When soil volume is restricted, soil quality becomes very important. High-quality soil and intensive maintenance can compensate for limited root space volume to a limited extent. When soil was amended with organic matter to $60 \mathrm{~cm}$ depth, root development was greater than when just the upper $15 \mathrm{~cm}$ was amended (Smith et al. 2010).

It is generally accepted that when soil volumes are combined and shared by several trees, the performance of the trees seems to be better than when trees are in several smaller, individual planting pits of the same total volume. Research to support this observation is limited. Condition of live oaks (Quercus virginiana) was better in shared planting spaces but not lacebark elm (Ulmus parvifolia) or red maple (Acer rubrum). Maples performed poorly in all root spaces, and other factors may have been more limiting than shared root space. The elms performed well even in very limited, non-shared root spaces and may be less sensitive to small root spaces (Kent et al. 2006).

\section{Expanding Root Space}

Soils under pavements can be very difficult for root growth. The pavement itself can have mixed effects on the root environment beneath it. Soil moisture can be greater under pavement than surrounding unpaved areas because of reduced evaporation (Hodge and Boswell 1993; Arnold and McDonald 2009). Maximum summer soil temperatures under pavement exposed to sun can be up to $10^{\circ} \mathrm{C}$ warmer than nearby unpaved 
areas and exceed levels that injure tree roots (Halverson and Heisler 1981; Graves and Dana 1987). The soil compaction necessary to support stable pavement often restricts root growth. Several approaches have been used to provide suitable conditions for root growth under pavements without compromising stability of the pavement.

\section{Pervious Paving}

It has been suggested that pervious paving materials could improve the soil environment beneath pavements for better tree growth, but research has not yet shown this to be consistently true. Soil oxygen was insufficient for root growth (less than 12\% oxygen) for prolonged periods beneath two of five pervious paving products tested on park footpaths (Couenberg 2009). Differences in soil oxygen and moisture between impervious and pervious concrete pavements are inconsistent (Morgenroth and Buchan 2009; Viswanathan et al. 2011). Pervious concrete plots had greater soil moisture in deeper layers in some seasons, but not in summer when it would be most beneficial, and there was no difference in tree growth rates, leaf water potential, or gas exchange (Volder et al. 2009). The narrow pavements (less than $1.5 \mathrm{~m}$ wide) used in these studies may allow water and oxygen to diffuse under the pavement from the edges of the solid pavement, just as effectively as through the pores of the pervious pavement.

To function correctly, pervious concrete pavement systems must have underlying soil that percolates well, which should also be beneficial for roots. If soil beneath the porous pavement is too compacted, the resulting poor soil aeration and penetration resistance are more likely to factor in limiting tree performance than the pavement (Viswanathan et al. 2011).

\section{Structural Soils}

Soils designed to support pavement without settling are often called load-bearing, skeletal, or structural soils. To expand root space under pavement in this way, the soil must provide a favorable environment for root growth while supporting the pavement.

The first soil of this type developed was called Amsterdam Tree Soil. Specifications call for 91\%94\% medium coarse sand, $4 \%-5 \%$ organic matter, and $2 \%-4 \%$ clay (by weight). Phosphorous and potassium are added as necessary. The organic matter provides a source of nitrogen (Couenberg 1993).
The soil mix is carefully compacted to a $70 \%-80 \%$ Proctor density when installed, and aeration is provided through spaces in the pavers placed over the soil. Callery pear (Pyrus calleryana) trees grew almost twice as rapidly in Amsterdam Tree Soil compared to standard pavement construction, and $50 \%$ faster than those grown in grass (Rahman et al. 2011).

Stone-soil mix structural soils create a network of interconnected spaces between the stones that can be filled with soil for root growth. When mixed and installed properly, structural stone-soil mixes compacted to $1.85 \mathrm{~g} \mathrm{~cm}^{-3}$, and greater, and did not reduce macropore space or restrict root penetration in the soil between the stones (Grabosky and Bassuk 1996; Grabosky et al. 2009). In a container study, structural soil held $7 \%-11 \%$ moisture by volume, similar to a loamy sand, and had high infiltration and good drainage and aeration (Grabosky et al. 2009), but no field measurements have been reported.

Early tests of structural soil mixes in containers showed that stone-soil mixes could support better root and top growth than compacted soils or typical road base materials (Grabosky and Bassuk 1995; Kristoffersen 1999). Growth was limited by net soil volume rather than the total volume of the stone-soil mix (Loh et al. 2003). The root:crown ratio was greater in stone mixes than topsoil alone, indicating a larger root system was needed for absorption of water and nutrients when the soil was spread out in the mix (Kristoffersen 1999).

Results of field studies have been mixed. At three and ten years after installation, growth $(\mathrm{DBH}$, height, canopy width) of trees planted in structural soil under pavement was equal to trees planted at the same time in a lawn adjacent to the sidewalk (Grabosky et al. 2002; Grabosky and Bassuk 2008). However, the trees planted in structural soil were within a few feet of an adjacent open-lawn area and the possibility that their roots may have grown into that soil volume was not addressed in the report. Other reports show that trees planted in non-compacted soils in open planters (Bühler et al. 2007) or covered by suspended pavement (Smiley et al. 2006) will outperform structural soil mixes. Stone-soil mixes can be a useful compromise in situations where high quality non-compacted soils cannot be used, but will not produce the same results in an equal volume of quality soil. 
Structural soils may increase tree anchorage. Trees were more stable in structural soils than traditional tree pits due to greater root length in gravel-based skeletal soil (Bartens et al. 2010). This is supported by a computer model in which a $20 \%$ soil to $80 \%$ granite chip mix was optimum for withstanding wind forces required to uproot trees (Rahardjo et al. 2009).

\section{Suspended Pavement}

If the pavement is suspended above the soil, the soil does not have to be compacted to support it. Suspended pavements range from elaborate designs constructed on-site to simpler and smaller precast concrete structures. Trees grew better in non-compacted soils under suspended pavement than in compacted soil or two structural soil types (Smiley et al. 2006). The study design did not include non-compacted soil without pavement over it, though experience has shown that trees will grow even better in open soil.

\section{Root Paths}

Root paths are narrow trenches installed in a compacted subgrade under pavement to provide a path for roots to grow from restricted planting pits to open spaces on the other side of the pavement. Commercially available strip-drain material is usually installed in the trench and then backfilled with loam soil (Costello and Jones 2003; Urban 2008). It could take several years for roots to grow through the root path and access the soil beyond. There is not yet any research to show that roots are able to effectively take advantage of the paths to access the soil beyond the pavement and improve tree growth and longevity, or that if roots do utilize the paths that they will not lift the pavement.

Soil conditions suitable for root growth under pavements also provide some level of stormwater storage (Day and Dickinson 2008). If significant, this could be additional justification for the higher cost of the expanded root space.

\section{ENHANCING ROOT DEVELOPMENT}

\section{Irrigation}

Trees are not irrigated in their natural environment. Healthy, established urban trees with adequate root space of quality soil are not typically dependent on irrigation if they are adapted to the climate in which they are growing. Little research is available on irrigation needs of established urban trees. A greenhouse study of ponderosa pine (Pinus ponderosa) showed that when water stress occurred during active root growth, the root:shoot ratio was reduced. When water stress occurred during active shoot growth, the root:shoot ratio was increased (McMillin and Wagner 1985; Silva et al. 2012).

Transpiration rates and pan evaporation are strongly correlated for woody species. Transpiration of larger trees is approximately $20 \%$ of pan evaporation (Knox 1989; Lindsey and Bassuk 1991). Because of more direct sunlight on the south side of the tree there may be greater water stress on the south side of the tree (Watson and Himelick 1982b; von der Heide-Spravka and Watson 1990). Increased irrigation may be appropriate on the south side of larger trees to compensate. Trickle irrigation can concentrate root development within the wet zones near the emitters (Levin et al. 1979; Mitchell and Chalmers 1983; Fernandez et al. 1991; Watson et al. 2006; Sokalska et al. 2009). Less frequent irrigation with the same amount of water can result in a wider distribution of roots (Levin et al. 1979).

In the summer, soils moist from irrigation and drainage changes can be a major cause of oak (Quercus) mortality in Mediterranean climates (Costello et al. 2011). The moisture and warm soil temperatures create conditions favorable to the development of root and crown rot diseases (Swiecki 1990).

Controlled studies of irrigation needs of large trees subject to root severing and loss are difficult to conduct, but studies on irrigation of transplanted trees with substantial root loss can provide information. Newly planted trees have reduced growth if subjected to water stress after transplanting (Haase and Rose 1993). Applying excessive irrigation may reduce root growth and increase the time needed for the tree to develop enough of a root system to survive without irrigation (Gilman et al. 2009). Proper irrigation can reduce secondary stressrelated problems, such as bark cracks, sunscald, and injury from borers (Roppolo and Miller 2001).

\section{Fertilization}

Total tree root system development is greater when soil nutrients are low (Kodrik and Kodrik 2002). Fertilization may not stimulate root growth unless low levels are already limiting root growth (Philipson and Coutts 1977). An increase in soil fertility 
is commonly associated with a reduction in the root:shoot ratio; that is, shoot growth increases more than root growth (Ingestad 1960; Philipson and Coutts 1977; Coutts and Philipson 1980; Nambiar 1980; Yeager and Wright 1981; Gleason et al. 1990; Warren 1993; Lloret et al. 1999; Jose et al. 2003; Qu et al. 2003; Rytter et al. 2003).

Fertility can alter the distribution of roots. Fine roots will grow preferentially in pockets of nitrogen rich soil (Wahlenberg 1929), by stimulating the growth of lateral roots (May et al. 1964; Hackett 1972; Eissenstat and Caldwell 1988; Witt 1997). Root growth may be increased even more when nitrogen availability is low outside the pocket (Krasowski et al. 1999). Application of nitrogen to a part of the root system has a strictly localized effect and does not increase overall root growth or alter the shoot:root ratio (Smith 1965; Drew et al. 1973; Drew and Saker 1975; Coutts and Philipson 1976; Carlson 1981; Carlson and Presig 1981; Friend et al. 1990; Sheriff and Nambiar 1995). Enhanced growth of one part of the root system can reduce growth in the other (Weller 1966; Phillipson and Coutts 1977). Severe soil compaction reduced nitrogen fertilizer uptake and was presumably related to the reduced uptake by a smaller root system (Jordan et al. 2003).

Fertilization may be necessary to maintain appropriate vigor and growth rates of urban trees if natural nutrient cycling is interrupted through the removal of fallen leaves and branches. In an Eastern deciduous hardwood forest, nitrogen in fallen litter was measured at $0.27-0.46 \mathrm{~kg} \mathrm{~N} / 100 \mathrm{~m}^{2} / \mathrm{yr}$ (Wells et al. 1972; Larcher 1975). Arboricultural best management practices (Smiley et al. 2007; ANSI 2011) recommend $0.96-1.44 \mathrm{~kg} \mathrm{~N} / 100 \mathrm{~m}^{2}$, but allow up to $2.88 \mathrm{~kg} \mathrm{~N} / 100 \mathrm{~m}^{2}$. These rates far exceed nutrients lost through litter removal and may not be appropriate for slower growing mature trees. Lawn fertilization alone may more than replace nutrients lost by removal of litter (Osmond and Hardy 2004).

\section{Root Stimulants}

Paclobutrazol, uniconazole, and flurprimidol are gibberellin-inhibiting growth regulators used primarily to reduce shoot growth of trees, but can also increase root growth under certain circumstances (Numbere et al. 1992). Paclobutrazol may promote root initiation (Davis et al. 1985). Pin oak (Quercus palustris) and white oak (Quercus alba) fine-root densities were increased significantly throughout the root system by a basal soil drench of paclobutrazol. The treatment may be effective in stabilizing slowly declining trees with insufficient fine-root development (Watson 1996; Watson and Himelick 2004). Fine-root density was not affected by paclobutrazol treatment in a high quality soil environment from long-term mulched application where root density may have been high initially, limiting the ability of paclobutrazol to increase them further (Watson 2006). Species may differ in their response to paclobutrazol. Growth of green ash (Fraxinus pennsylvanica) roots was unaffected by paclobutrazol treatment (Watson 2004). Theability of paclobutrazol to increase root growth may depend on root-leaf area ratio. Paclobutrazol applied at planting doubled root growth on black maple (Acer nigrum) in the first season before crown growth was reduced by the paclobutrazol treatment, but not the second when crown growth was greatly reduced (Watson 2004). The large reduction in top growth may have been responsible for the lack of root stimulation in the second year. Gilman (2004) also reported that paclobutrazol had no effect on root growth of transplanted live oaks (Quercus virginiana) at a rate that reduced top growth. Root pruning can enhance the growth regulation effects of paclobutrazol treatment and slow root growth (Martinez-Trinidad et al. 2011).

Soil applications of sugar solutions have been tested to increase root growth. Root growth is often but not always increased and may depend on tree species, kinds of sugars, and application rates included in the trials (Percival 2004; Percival et al. 2004; Percival and Fraser 2005; Percival and Barnes 2007; Martinez-Trinidad et al. 2009). Measurable increases in tree vitality are uncommon, even on small experimental plants.

There is extensive published research from a broad spectrum of plant sciences that can be applied to the prevention and mitigation of human impacts on urban tree root systems. The majority of literature available on structural soils, tree root architecture, root locating methods, and root defects has been produced in the last 25 years. At the same time, advances have been made in understanding topics such as infrastructure conflicts and fertiliza- 
tion practices, but these advances are still not fully understood. Arboricultural science is young and growing. There is hardly a topic that would not benefit from extensive additional research. The wide variety of species and environmental circumstances in urban landscapes makes it especially challenging.

Acknowledgments. We would like to thank the International Society of Arboriculture and the ISA Science and Research Committee for funding this literature review.

\section{LITERATURE CITED}

Abod, S.A. 1990. Effects of nutrients deficiencies on the root regenerating potential and growth of Pinus caribaea and Pinus kesiya seedlings. Pertanika 13:145-150.

Abod, S.A., and A.D. Webster. 1990. Shoot and root pruning effects on the growth and water relations of young Malus, Tilia, and Betula transplants. Journal of Horticultural Science 65:451-459.

Abod, S.A., and S. Sandi. 1983. Effect of restricted watering and its combination with root pruning on root growth capacity, water status and food reserves of Pinus caribaea var. hondurensis seedlings. Plant and Soil 71:123-129.

Achinelli, F.G., J.L. Marquina, and R.M. Marlats. 1997. Exploratory study of the relationships between tree growth, site conditions, and maintenance practices in street plantings of Fraxinus pennsylvanica Marshall of La Plata City, Argentina. Arboricultural Journal 21:305-315.

Ahrens, J.F., O.A. Leonard, and N.R. Townley. 1970. Chemical control of tree roots in sewer lines. Water Pollution Control Federation 42:1643-1655.

Al-Mana, F.A., and D.J. Beattie. 1996. Effects of hormone-charged hydrophilic polymer on root regeneration in red oak and black gum transplants. Acta Horticulturae 429:459-466.

American National Standard Institute. 2011. American National Standard for Tree Care Operations - Tree, Shrub, and Other Woody Plant Maintenance - Standard Practices (Soil Management - a. Modification, b. Fertilization, and c. Drainage) (A300, Part 2). Tree Care Industry Association, Manchester, New Hampshire, U.S. 20 pp.

Andersen, C.P., E.I. Sucoff, and R.K. Dixon. 1986. Effects of root zone temperature on root initiation and elongation in red pine seedlings. Canadian Journal of Forest Research 16:696-700.

Anonymous. 2004. American Standards for Nursery Stock, ANSI Z60.1. American Association of Nurserymen, Washington, D.C. 113 pp. Accessed 05/21/2013. <www.anla.org/docs/About\%20 ANLA/Industry\%20Resources/ANLAStandard2004.pdf>

Anonymous. 2010. European Technical \& Quality Standards for Nurserystock. Accessed 05/21/2013. <www.enaplants.eu>

Appel, D.N. 1994. Identification and control of oak wilt in Texas urban forests. Journal of Arboriculture 20:250-258.

Arnold, M.A. 1996. Mechanical correction and chemical avoidance of circling roots differentially affect post-transplant root regeneration and field establishment of container-grown Shumard oak. Journal of American Society of Horticultural Science 121:258-263.

Arnold, M.A., and D.K. Struve. 1989. Green ash establishment following transplant. Journal of American Society of Horticultural Science 114:591-595.
Arnold, M.A., and G.V. McDonald. 2009. Groundcovers, organic and inorganic mulches, and masonry surfaces differentially affect establishment and root zone characteristics of urban trees. Arboriculture \& Urban Forestry 35:232-240.

Bader, C. 2000. Untersuchungen über den statisch wirksamen Wurzelraum. [Investigations on the stability relevant root zone] Fachhochschule. [University of Applied Sciences] Nürtingen, Germany.

Balder, H. 1999. Mechanical root injuries: Compartmentalization, pruning, and wound dressing. Acta Horticulturae 496:239-244.

Balder, H., D. Dujesiefken, T. Kowol, and E. Schmitz-Felten. 1995. Zur Wirkung von Wundbehandlungen an Wurzeln bei Eiche und Linde [Aspects of wound treatments of oak and basswood roots]. Nachrichtenblatt des Deutschen Pflanzenschutzdienstes 47:28-35.

Barker, P.A. 1983. Some urban trees of California: Maintenance problems and genetic improvement possibilities. pp. 47-54. In: Proceedings of the Fourth Conference of the Metropolitan Tree Improvement Alliance.

Barker, P.A. 1995a. Managed development of tree roots. I. Ultradeep root ball and root barrier effects on European hackberry. Journal of Arboriculture 21:202-208.

Barker, P.A. 1995b. Managed development of tree roots. II. Ultradeep root ball and root barrier effects on Southwestern black cherry. Journal of Arboriculture 21:251-258.

Bartens, J., P.E. Wiseman, and E.T. Smiley. 2010. Stability of landscape trees in engineered and conventional urban soil mixes. Urban Forestry \& Urban Greening 9:333-338.

Barton, C.V.M., and K.D. Montagu. 2004. Detection of tree roots and determination of root diameters by ground penetrating radar under optimal conditions. Tree Physiology 24:1323-1331.

Bassuk, N., J. Grabosky, A. Mucciardi, and G. Raffel. 2011. Groundpenetrating radar accurately locates tree roots in two soil media under pavement. Arboriculture \& Urban Forestry 37:160-166.

Biddle, P.G. 1998. Tree Root Damage to Buildings. Volume I: Causes, Diagnosis and Remedy. Willowmead Publishing, Ltd. Wantage, UK. 376 pp.

Blackwell, P.G., K. Rennolls, and M. Coutts. 1990. A root anchorage model for shallowly rooted Sitka spruce. Forestry 63:73-91.

Blessing, S.C., and M.N. Dana. 1987. Post-transplant root system expansion in Juniperus chinensis L. as influenced by production system, mechanical root disruption and soil type. Journal of Environmental Horticulture 5:155-158.

Blunt, S.M. 2008. Trees and pavements - are they compatible? Arboricultural Journal 31:73-80.

Bronnum, P. 2005. Preplanting indicators of survival and growth of desiccated Abies procera bare root planting stock. Scandinavian Journal of Forest Research 20:36-46.

Broschat, T.K., and H. Donselman. 1990a. Regeneration of severed roots in Washingonia robusta and Phoenix reclinata. Principes 34:96-97.

Broschat, T.K., and H. Donselman. 1990b. IBA, plant maturity, and regeneration of palm root systems. HortScience 25:232.

Broschat, T.K., and H.M. Donselman. 1984. Regrowth of severed palm roots. Journal of Arboriculture 10:238-240.

Bühler, O., P. Kristoffersen, and S.U. Larsen. 2007. Growth of street trees in Copenhagen with emphasis on the effect of different establishment concepts. Arboriculture \& Urban Forestry 33:330-337. 
Burdett, A.N. 1978. Control of root morphogenesis for improving mechanical stability in container-grown lodgepole pine. Canadian Journal of Forest Research 8:483-486.

Burdett, A.N. 1981. Box-pruning the roots of container grown tree seedlings. pp 203-206 In: J.B. Scarratt, C. Glerum, and C.A. Plexman (Eds.). Proceedings of the Canadian containerized tree seedling symposium. Canadian Forestry Service, Great Lakes Forest Research Centre, Sault Ste. Marie, Ontario, Canada.

Burger, D.W., and T.E. Prager. 2008. Deep-rooted trees for urban environments: selection and propagation. Arboriculture \& Urban Forestry 34:184-190.

Butnor, J.R., J. A. Doolittle, K.H. Johnsen, L. Samuelson, T. Stokes, and L. Kress. 2003. Utility of ground-penetrating radar as a root biomass survey tool in forest systems. Soil Science Society of America Journal 67:1607-1615.

Butnor, J.R., J.A. Doolittle, L. Kress, S. Cohen, and K.H. Johnsen. 2001. Use of ground-penetrating radar to study tree roots in the southeastern United States. Tree Physiology 21:1269-1278.

Carlson, W.C. 1974. Root initiation induced by root pruning in northern red oak. Forest Research Review, Ohio Agricultural Research and Development Center, Wooster, Ohio. pp. 14-16.

Carlson, W.C. 1981. Effects of controlled-release fertilizers on shoot and root development of out-planted western hemlock (Tsuga heterophylla RAF. SARG) Seedlings. Canadian Journal of Forest Research 11:752-757.

Carlson, W.C. 1986. Root system considerations in the quality of loblolly pine seedlings. Southern Journal of Applied Forestry 10:87-92.

Carlson, W.C., and C.L. Preisig. 1981. Effects of controlled-release fertilizers on the shoot and root development of Douglas-fir seedlings. Canadian Journal of Forest Research 11:230-242.

Castle, W.S. 1983. Antitranspirant and root canopy pruning effects on mechanically transplanted eight-year-old Murcott citrus trees. Journal of American Society of Horticultural Science 108:981-985.

Catena, A. 2003. Thermography reveals hidden tree decay. Arboricultural Journal 27:27-42.

Cellerino, G.P., and G. Nicolotti. 1998. Which techniques should be used to diagnose urban tree root rot? Informatore Fitopatologico 48:45-50.

Cermak, J., J. Hruska, M. Martinkova, and A. Prax. 2000. Urban tree root systems and their survival near houses analyzed using ground-penetrating radar and sap flow techniques. Plant and Soil 219:103-116.

Costello, L.R., and K.S. Jones. 2003. Reducing Infrastructure Damage by Tree Roots: A Compendium of Strategies. WCISA, Cohasset, CA. 119 pp.

Costello, L.R., B.W. Hagen, and K.S. Jones. 2011. Oaks in the Urban Landscape: Selection, Care, and Preservation. University of California Agriculture and Natural Resources Publication 3518. 265 pp.

Costello, L.R., C.L. Elmore, and S. Steinmaus. 1997. Tree root response to circling root barriers. Journal of Arboriculture 23:211-218.

Couenberg, E.A.M. 1993. Amsterdam tree soil. pp. 24-33. In: G. Watson and D. Neely (Eds.). The Landscape Below Ground. International Society of Arboriculture, Savoy, Illinois, U.S.

Couenberg, E.A.M. 2009. A preliminary study evaluating oxygen status beneath different surface-hardening materials for park use. pp. 189-202. In: G.W. Watson and D. Neely (Eds.). The
Landscape Below Ground III. International Society of Arboriculture, Champaign, Illinois, U.S.

Coutts, M.P. 1979. The physiological characteristics of trees, and damage to buildings by root activity. Arboricultural Journal 3:413-419.

Coutts, M.P. 1983. Root architecture and tree stability. Plant and Soil 71:171-188.

Coutts, M.P. 1986. Components of tree stability in Sitka spruce on peaty gley soil. Forestry 59:173-197.

Coutts, M.P., and J.J. Philipson. 1976. The influence of mineral nutrition on the root development of trees: I. The growth of Sitka spruce with divided root systems. Journal of Experimental Botany 27:1102-1111.

Coutts, M.P., and J.J. Philipson. 1980. Mineral nutrition and tree growth. pp. 123-26. In: D. Atkinson, J.E. Jackson, R.O. Sharpies, and W.M. Waller (Eds.). Mineral Nutrition of Fruit Trees. Butterworths, London, England.

Cuthbert, R.A., W.N. Cannon Jr., and J.W. Peacock. 1975. Relative Importance of Root Grafts and Bark Beetles to the Spread of Dutch Elm Disease. USDA Forest Service Research Paper NE-206. 4 pp.

Cutler, D.F., and I.B.K. Richardson. 1989. Tree roots and buildings. Longman Scientific \& Technical, Harlow, Essex, England. 71 pp.

Cutler, D.F., P.J. Rudall, P.E. Gasson, and R.M.O. Gale. 1987. Root Identification Manual of Trees and Shrubs: A Guide to the Anatomy of Roots of Trees and Shrubs Hardy in Britain and Northern Europe. Chapman and Hall, London, England. 245 pp.

D’Amato, N.E., T.D. Sydnor, M. Knee, R. Hunt, and B. Bishop. 2002a. Which comes first, the root or the crack? Journal of Arboriculture 28:277-282.

D’Amato, N.E., T.D., Sydnor, R. Hunt, and B. Bishop. 2002b. Root growth beneath sidewalks near trees of four genera. Journal of Arboriculture 28:283-290.

d'Ambrosio, R.P. 1990. Crown density and its correlation to girdling root syndrome. Journal of Arboriculture 16:153-157.

Davis, T.D., N. Sankhla, R.H. Walser, and A. Upadhyaya. 1985. Promotion of adventitious root formation on cuttings by paclobutrazol. HortScience 20:883-885.

Day, R.W. 1991. Damage of structures due to tree roots. Journal of Performance of Constructed Facilities 5:200-207.

Day, S.D., and J.R. Harris. 2008. Growth, survival, and root system morphology of deeply planted Corylus colurna 7 years after transplanting and the effects of root collar excavation. Urban Forestry \& Urban Greening 7:119-128.

Day, S.D., and S.B. Dickinson (Eds.). 2008. Managing Stormwater for Urban Sustainability Using Trees and Structural Soils. Virginia Polytechnic Institute and State University, Blacksburg, Virginia, U.S. 63 pp.

Day, S.D., J.R. Harris, and R.J. Stipes. 2006. Buried trunks: How deep planting affects trunk tissue, adventitious rooting, and tree growth. pp. 45-48. In: Trees and Planting: Getting the Roots Right, The Morton Arboretum, Lisle, Illinois, U.S. Accessed 05/21/2013. <www.mortonarb.org/deeptreeroots/pdf/GRR_ Proceedings.pdf\#TOC>

Day, S.D., J.R. Seiler, R. Kreh, and D.W. Smith. 2001. Overlaying compacted or uncompacted construction fill has no negative impact on white oak and sweetgum growth and physiology. Canadian Journal of Forest Research 31:100-109. 
Day, S.D., P.E. Wiseman, S.B. Dickinson, and J.R. Harris. 2010. Contemporary concepts of root system architecture or urban trees. Arboriculture \& Urban Forestry 36:149-159.

DeGaetano, A.T. 2000. Specification of soil volume and irrigation frequency for urban tree containers using climate data. Journal of Arboriculture 26:142-150.

Drew, M.C, L.R. Saker, and T.W. Ashley. 1973. Nutrient supply and the growth of the seminal root system in barley. Journal of Experimental Botany 24:1189-1202.

Drew, M.C., and L.R. Saker. 1975. Nutrient supply and the growth of the seminal root system in barley: II. Localized, compensatory increases in lateral root growth and rates of nitrate uptake when nitrate supply is restricted to only part of the root system. Journal of Experimental Botany 26:79-90.

Drilias, M.J., J.E. Kuntz, and G.L. Worf. 1982. Collar rot and basal canker of sugar maple. Journal of Arboriculture 8:29-33.

Eissenstat, D.M., and M.M. Caldwell. 1988. Seasonal timing of root growth in favorable microsites. Ecology 69:870-873.

Ellyard, R.K. 1984. Effect of root pruning at time of planting on subsequent root development of two species of eucalyptus. Journal of Arboriculture 10:241-216.

Fare, D.C. 2006. Should potting depth be a concern with containergrown trees? pp. 25-29. In: Proceedings of Trees and Planting: Getting the Roots Right, Lisle, Illinois. Accessed 05/21/2013. <www. mortonarb.org/deeptreeroots/pdf/GRR_Proceedings.pdf\#TOC>

Fernandez, J.E., F. Moreno, F. Cabrera, J.L. Arrue, and J. Martinandra. 1991. Drip irrigation, soil characteristics and the root distribution and root activity of oil trees. Plant and Soil 133:239-251.

Fluckiger, W., and S. Braun. 1999. Stress factors of urban trees and their relevance for vigour and predisposition for parasite attacks. Acta Horticulturae 496:325-334.

Fourcaud, T., J.N. Ji, Z.Q. Zhang, and A. Stokes. 2008. Understanding the impact of root morphology on overturning mechanisms: A modeling approach. Annals of Botany 101:1267-1280.

Fraedrich, B.R., and E.T. Smiley. 2002. Assessing the failure potential of tree roots. pp. 159-163. In: E.T. Smiley and K.D. Coder (Eds.). Tree Structure and Mechanics Conference Proceedings: How Trees Stand Up and Fall Down. International Society of Arboriculture, Champaign, Illinois, U.S.

Francis, J.K., B.R. Parresol, and J.M. de Patino. 1996. Probability of damage to sidewalks and curbs by street trees in the tropics. Journal of Arboriculture 22:193-197.

Friend, A.L., M.R. Eide, and T.M. Hinckley. 1990. Nitrogen stress alters root proliferation in Douglas-fir seedlings. Canadian Journal of Forest Research 20:1524-1529.

Fuchs, H.W.M. 1986. Root regeneration of rose plants as influenced by applied auxins. Acta Horticulturae 189:101-107.

Garbelotto, M., G. Slaughter, T. Popenuck, F.W. Cobb, and T.D. Bruns. 1997. Secondary spread of Heterobasidion annosum in white fir root-disease centers. Canadian Journal of Forest Research 27:766-773.

Ghani, M.A., A. Stokes, and T. Fourcaud. 2009. The effect of root architecture and root loss through trenching on the anchorage of tropical urban trees (Eugenia grandis Wight). Trees: Structure and Function 23:197-209.

Gibbs, J.N., and D.W. French. 1980. The Transmission of Oak Wilt. USDA. Forest Service Research Paper NC-185.

Giblin, C., J. Gilman, D. Hanson, G. Johnson, and P. Weicherding. 2005. The effects of soil depth on the long-term health and frequency of storm damage to trees in the upper Midwest. pp.
33-39. In: Proceedings of Trees and Planting: Getting the Roots Right. Accessed 05/21/2013. <www.mortonarb.org/deeptreeroots/pdf/GRR_Proceedings.pdf\#TOC $>$

Gilman, E.F. 1990. Tree root growth and development. II. Response to culture, management and planting. Journal of Environmental Horticulture 8:220-227.

Gilman, E.F. 1996. Root barriers affect root distribution. Journal of Arboriculture 22:151-154.

Gilman, E.F. 2004. Effects of amendments, soil additives, and irrigation on tree survival and growth. Journal of Arboriculture 30:301-310.

Gilman, E.F. 2006. Deflecting roots near sidewalks. Arboriculture \& Urban Forestry 32:18-22.

Gilman, E.F., and C. Harchick. 2008. Planting depth in containers affects root form and tree quality. Journal of Environmental Horticulture 26:129-134.

Gilman, E.F., and F.J. Masters. 2010. Effect of tree size, root pruning, and production method on root growth and lateral stability of Quercus virginiana. Arboriculture \& Urban Forestry 36:281-291.

Gilman, E.F., and M.E. Kane. 1990. Root growth of red maple following planting from containers. Hortscience 25:527-528.

Gilman, E.F., and R.C. Beeson. 1996. Production method affects tree establishment in the landscape. Journal of Environmental Horticulture 14:81-87.

Gilman, E.F., and T.H. Yeager. 1988. Root initiation in root-pruned hardwoods. HortScience 23:351.

Gilman, E.F., C.L. Wiese, M. Paz, A.L. Shober, S.M. Scheiber, K.A. Moore, and M. Brennan. 2009. Effects of irrigation volume and frequency on shrub establishment in Florida. Journal of Environmental Horticulture 27:149-154.

Gilman, E.F., M. Paz, and C. Harchick. 2010. Root ball shaving improves root systems on seven species in containers. Journal of Environmental Horticulture 28:13-18.

Gilman, E.F., T.H. Yeager, and D. Weigle. 1996. Fertilizer, irrigation and root ball slicing affects Burford holly growth after planting. Journal of Environmental Horticulture 14:105-110.

Gleason, J.F., M. Duryea, R. Rose, and M. Atkinson. 1990. Nursery and field fertilization of $2+0$ ponderosa pine seedlings: The effect on morphology, physiology, and field performance. Canadian Journal of Forest Research 20:1766-1772.

Goodwin, C., and G. Lumis. 1992. Embedded wire in tree roots implications for tree growth and root function. Journal of Arboriculture 18:115-123.

Gossard, A.C. 1942. Root and shoot production by young pecan trees treated with indole-butyric acid at the time of transplanting. Proceedings of the American Society for Horticultural Science 41:161-166.

Gouin, F.R. 1983. Girdling roots, fact or fiction. International Plant Propagators Society 33:428-432.

Grabosky, J., and E. Gilman. 2004. Measurement and prediction of tree growth reduction from tree planting space design in established parking lots. Journal of Arboriculture 30:154-164.

Grabosky, J., and N. Bassuk. 1995. A new urban tree soil to safely increase rooting volumes under sidewalks. Journal of Arboriculture 21:187-201.

Grabosky, J., and N. Bassuk. 1996. Testing of structural urban tree soil materials for use under pavement to increase street tree rooting volumes. Journal of Arboriculture 22:255-263. 
Grabosky, J., and N. Bassuk. 2008. Sixth- and tenth-year growth measurements for three tree species in a load-bearing stone-soil blend under pavement and a tree lawn in Brooklyn, New York, U.S. Arboriculture \& Urban Forestry 34:265-266.

Grabosky, J., E. Haffner, and N. Bassuk. 2009. Plant available moisture in stone-soil media for use under pavement while allowing urban tree root growth. Arboriculture \& Urban Forestry 35:271-278.

Grabosky, J., N. Bassuk, and B.Z. Marranca. 2002. Preliminary findings from measuring street tree shoot growth in two skeletal soil installations compared to tree lawn plantings. Journal of Arboriculture 28:106-108.

Grabosky, J., N. Bassuk, L. Irwin, and H. Van Es. 2001. Shoot and root growth of three tree species in sidewalks. Journal of Environmental Horticulture 19:206-211.

Graham, B.F., and F.H. Bormann. 1966. Natural root grafts. Botanical Review 32:255-292.

Graves, W.R., and M.N. Dana. 1987. Root-zone temperature monitored at urban sites. HortScience 22:613-614.

Grene, S. 1978. Root deformations reduce root growth and stability. pp. 150-155. In: E. Van Eerden and J.M. Kinghorn (Eds.). Proceedings of the Root Form of Planted Trees Symposium. British Columbia Ministry of Forests/Canadian Forest Service Joint Report No. 8, Victoria, British Columbia, Canada.

Haase, D.I., and R. Rose. 1993. Soil moisture stress induces transplant shock in stored and unstored 2+0 Douglas-fir seedlings of varying root volume. Forest Science 39:275-294.

Hackett, C. 1972. A method of applying nutrients locally to roots under controlled conditions, and some morphological effects of locally applied nitrate on the branching of wheat roots. Australian Journal of Biological Sciences 25:1169-1180.

Halter, M.R., C.P. Chanway, and G.J. Harper. 1993. Growth reduction and root deformation of containerized lodgepole pine saplings 11 years after planting. Forest Ecology and Management 56:131-146.

Halverson, H.G., and G.M. Heisler. 1981. Soil Temperatures Under Urban Trees and Asphalt. USDA Forest Service Research Paper NE-481.

Hamilton, W.D. 1988. Significance of root severance on performance of established trees. Journal of Arboriculture 14:288-292.

Harris, J.R., J.K. Fanelli, A.X. Niemiera, and R.D. Wright. 2001. Root pruning pin oak liners affects growth and root morphology. HortTechnology 11:49-52.

Harris, R.W., J. Clark, and N.M. Matheny. 1999. Arboriculture: the Integrated Management of Trees, Shrubs, and Vines. Third Edition. Prentice-Hall, Englewood Cliffs, New Jersey, U.S.

Hauer, R.J., R.W. Miller, and D.M. Ouimet. 1994. Street tree decline and construction damage. Journal of Arboriculture 20:94-97.

Hewitt, A., and G. Watson. 2009. Bare root liner production can alter tree root architecture. Journal of Environmental Horticulture 27:99-104.

Himelick, E.B., and H.W Fox. 1961. Experimental studies on control of oak wilt disease. Illinois Agricultural Experiment Station Technical Bulletin 680 .

Hipps, N. 2004. Controlling Water Use of Trees to Alleviate Subsidence Risk. Horticulture LINK Project 212, Final Report Executive Summary. University of Cambridge, UK. $114 \mathrm{pp}$.

Hirano, Y., M. Dannoura, K. Aono, T. Igarashi, M. Ishii, K. Yamase, N. Makita, and Y. Kanazawa. 2009. Limiting factors in the detection of tree roots using ground-penetrating radar. Plant and Soil 319:15-24.
Hodge, S.J., and R. Boswell. 1993. A study of the relationship between site conditions and urban tree growth. Journal of Arboriculture 19:358-367.

Holmes, F.W. 1984. Effects on maples of prolonged exposure by artificial girdling roots. Journal of Arboriculture 10:40-44.

Horsley, S.B. 1971. Root tip injury and development of the paper birch root system. Forest Science 17:341-348.

Howland, P., and A.L. Griffith. 1961. The root development of transplants after planting in the field. Empire Forestry Review 40:66-70.

Hruska, J., J. Cermak, and S. Sustek. 1999. Mapping of tree root systems by means of the ground-penetrating radar. Tree Physiology 19:125-130.

Hudler, G.W., and M.A. Beale. 1981. Anatomical features of girdling root injury. Arboricultural Journal 5:131-136.

Hutchings, R.R., D. Sinnett, A.J. Peace, and A.J. Moffat. 2006. The effect of woodland growth on a containment landfill site in Hertfordshire, UK. Urban Forestry \& Urban Greening 5:169-176.

Ingestad, T. 1960. Studies on the nutrition of forest trees seedlings. III. Mineral nutrition of pine. Physiologia Plantarum 13:513-533.

Ingestad, T., and A-B. Lund. 1979. Nitrogen stress in birch seedlings I. Growth technique and growth. Physiologia Plantarum 45:137-48.

Ismail, M.R., and K.M. Noor. 1996. Growth, water relations and physiological processes of starfruit (Averrhoa carambola L.) plants under root growth restriction. Scientia Horticulturae 66:51-58.

Jacobs, K., B. Rao, B. Jeffers, and D. Danielson. 2000. The effect of Biobarrier on mycorrhizae in oak and sweetgum. Journal of Arboriculture 26:92-96.

Jane, G.T. 1969. The significance of natural root grafting in forestry. Journal of the Oxford Forest Society 6:14-16.

Johnson, P.S., S.L. Novinger, and W.G. Mares. 1984. Root, shoot, and leaf area growth potentials of northern red oak planting stock. Forest Science 30:1017-1026.

Jordan, D., F.J. Ponder, and V.C. Hubbard. 2003. Effects of soil compaction, forest leaf litter, and nitrogen fertilizer on two oak species and microbial activity. Applied Soil Ecology 23:33-41.

Jose, S., S. Merritt, and C.L. Ramsey. 2003. Growth, nutrition, photosynthesis and transpiration responses of longleaf pine seedlings to light, water, and nitrogen. Forest Ecology and Management 180:335-344.

Kent, D., S. Shultz, T. Wyatt, and D. Halcrow. 2006. Soil Volume and Tree Condition in Walt Disney World Parking Lots. Landscape Journal 25:94-107.

Knox, G.W. 1989. Water use and average growth index of five species of container grown woody landscape plants. Journal of Environmental Horticulture 7:136-139.

Kodrik, J., and M. Kodrik. 2002. Root biomass of beech as a factor influencing the wind tree stability. Journal of Forest Science 48:549-564.

Kopinga, J. 1985. Research on street tree planting practices in the Netherlands. pp. 72-84. In: L.J. Kuhns and J.C. Patterson (Eds.). METRIA:5 Proceedings. Pennsylvania State University, University Park, Pennsylvania, U.S.

Kopinga, J. 1991. The effects of restricted volumes of soil on the growth and development of street trees. Journal of Arboriculture 17:57-63. 
Kopinga, J. 1994a. Aspects of the damage to asphalt road pavings caused by tree roots. pp. 165-178. In: G. Watson and D. Neely (Eds.). The Landscape Below Ground. International Society of Arboriculture, Savoy, Illinois, U.S.

Kopinga, J. 1994b. Some aspects of the damage to asphalt road pavings caused by tree roots, including some preventive control methods. pp. 10.1-10.23. In: Proceedings from the 10th Osnabrucker Baumpflegetage.

Kormanik, P.P. 1986. Lateral root morphology as an expression of sweetgum seedling quality. Forest Science 32:595-604.

Kormanik, P.P. 1988. Frequency distribution of first-order lateral roots in forest tree seedlings: Silvicultural implications. pp. 101-105. In: Proceedings 5th Biennial Southern Silvicultural Research Conference. USDA Forest Service Gen. Tech. Rep. SO-74.

Kormanik, P.P., J.L. Ruehle, and H.D. Muse. 1989. Frequency Distribution of Lateral Roots of 1-0 Bare-root White Oak Seedlings. USDA Forest Service Southeastern Forest Experiment Station Research Note SE-353.

Kormanik, P.P., S.S. Sung, D.J. Kass, and S. Schlarbaum. 1998. Effect of seedling size and first-order-lateral roots on early development of northern red oak on mesic sites. pp. 247-252. In: T.A. Waldrop (Ed.). Proceedings, 9th Biennial Southern Silvicultural Research Conference. USDA Forest Service, Southern Research Station General Technical Report SRS-20.

Krasowski, M.J., J.N. Owens, L.E. Tackaberry, and H.B. Massicotte. 1999. Above- and below-ground growth of white spruce seedlings with roots divided into different substrates with or without controlled-release fertilizer. Plant and Soil 217:131-143.

Kristoffersen, P. 1999. Growing trees in road foundation materials. Arboricultural Journal 23:57-76.

Larcher W. 1975. Physiological Plant Ecology. Springer-Verlag, New York, U.S. 252 pp.

Leonard, O.A., and N.R. Townley. 1971. Control of tree roots in sewers and drains California Agriculture 25(11):13.

Leonard, O.A., D.E. Bayer, and R.K. Glenn. 1974. Control of tree roots. Weed Science 22:516-520.

Levin, I., R. Assaf, and B. Bravdo. 1979. Soil moisture and root distribution in an apple orchard irrigated by tricklers. Plant and Soil 52:31-40.

Lidstrom, V. 1994. Change in structural condition in sewer pipes. Proceedings NODIG 94, Copenhagen, Denmark.

Lindsey, P., and N. Bassuk. 1991. Specifying soil volumes to meet the water needs of mature urban street trees and trees in containers. Journal of Arboriculture 17:141-149.

Lindsey, P., and N. Bassuk. 1992. Redesigning the urban forest from the ground below: A new approach to specifying adequate soil volumes for street trees. Arboricultural Journal 16:25-39.

Livingston, W.H. 1990. Armillaria ostoyae in young spruce plantations. Canadian Journal of Forest Research 20:1773-1778.

Lloret, F., C. Casanovas, and J. Penuelas. 1999. Seedling survival of Mediterranean shrubland species in relation to root, shoot ratio, seed size, and water and nitrogen use. Functional Ecology 13:210-216.

Loh, F.C.W., J.C. Grabosky, and N.L. Bassuk. 2003. Growth response of Ficus benjamina to limited soil volume and soil dilution in a skeletal soils container study. Urban Forestry \& Urban Greening 2:53-62.
Lumis, G.P., and S.A. Struger. 1988. Root tissue development around wire-basket transplant containers. HortScience 23:401.

Lumis, G.P. 1982. Stimulating root regeneration of landscape-size red oak with auxin root sprays. Journal of Arboriculture 8:325-326.

Lyons, C.G., K.S. Yoder, and R.E. Byers. 1982. Poor anchorage and growth of spur Red Delicious apple-trees with deep crown roots. Scientia Horticulturae 18:45-47.

MacDonald, J.D., L.R. Costello, J.M. Lichter, and D. Quickert. 2004. Fill soil effects on soil aeration and tree growth. Journal of Arboriculture 30:19-27.

Macleod, R.D., and W.J. Cram 1996. Forces exerted by tree roots. Arboriculture Research and Information Note J34/96/EXT. Arboricultural Advisory and Information Service, Farnham, England.

Magley, S.B., and D.K. Struve. 1983. Effects of three transplant methods on survival, growth and root regeneration of caliper pin oaks. Journal of Environmental Horticulture 1:59-62.

Marshall, D., D. Patch, and M. Dobson. 1997. Root Barriers and Building Subsidence. Arboricultural Practice Notes APN 4, 8 pp.

Martinez-Trinidad, T., W.T. Watson, and R.K. Book. 2011. Impact of paclobutrazol on root-pruned live oak. HortTechnology 21:46-50.

Martinez-Trinidad, T., W.T. Watson, M.A. Arnold, and L. Lombardini. 2009. Investigations of exogenous applications of carbohydrates on the growth and vitality of live oaks. Urban Forestry \& Urban Greening 8:41-48.

Mattheck, C., and K. Bethge. 2000. Biomechanical study on the interactions of roots with gas and water pipelines for the evaluation of tree sites. Arboricultural Journal 23:343-377.

May, L.H., F.H. Chapman, and D. Aspinall. 1964. Quantitative studies of root development. I. The influence of nutrient concentration. Australian Journal of Biological Sciences 18:25-35.

McClure, S. 1991. Fatal flaws (overlooking critical practices for planting B\&B material may prove deadly). American Nurseryman 174(8):58-61.

McMillin, J.D., and M.R. Wagner. 1995. Effects of water stress on biomass partitioning of Ponderosa pine seedlings during primary root growth and shoot growth periods. Forest Science 41:594-610.

McPherson, E.G. 2000. Expenditures associated with conflicts between street tree root growth and hardscape in California, United States. Journal of Arboriculture 26:289-297.

Miller, F.D., and D. Neely. 1993. The effect of trenching on growth and plant health of selected species of shade tree. Journal of Arboriculture 19:226-229.

Misra, R.K., and R. Sands. 1993. Water extraction by isolated trees and its possible impact on building foundations on clay soils. Australian Journal of Soil Research 31:25-37.

Mitchell, P.D., and D.J. Chalmers. 1983. A comparison of microjet and point emitter (trickle) irrigation in the establishment of a high-density peach orchard. HortScience 18:472-474.

Morell, J.D. 1984. Parkway tree auguring specifications. Journal of Arboriculture 10:129-132.

Morgenroth, J. 2008. A review of root barrier research. Arboriculture \& Urban Forestry 34:84-88.

Morgenroth, J., and G.D. Buchan. 2009. Soil moisture and aeration beneath pervious and impervious pavements. Arboriculture \& Urban Forestry 35:135-141. 
Morrison, D.J., and D.B. Redfern. 1994. Long-term development of Heterobasition annosum in basidiospore-infected Sitka spruce stumps. Plant Pathology 43:897-906.

Nadezhdina, N., and J. Cermak. 2003. Instrumental methods for studies of structure and function of root systems of large trees. Journal of Experimental Botany 54:1511-1521.

Nambiar, E.K. 1980. Root configuration and root regeneration in Pinus radiata seedlings. New Zealand Journal of Forest Science 10:249-263.

Neely, D., and E.B. Himelick. 1966. Effects of SMDC on elm roots. Plant Disease Reporter 50:473-476.

Nicoll, B.C., and A. Armstrong. 1997. Street tree root architecture and pavement damage. Arboriculture Research and Information Note138/97/SILN Arboricultural Advisory and Information Service, Farnham, Surrey, England.

Nicoll, B.C., and A. Armstrong. 1998. Development of Prunus root systems in a city street: Pavement damage and root architecture. Arboricultural Journal 22:259-270.

Nicoll, B.C., and M.P. Coutts. 1997. Direct Damage by Urban Tree Roots: Paving the way for less damaging street trees. pp. 77-84. In: J. Claridge (Ed.). Arboricultural Practice Present and Future Research for Amenity Trees No. 6. HMSO, England.

Nicoll, B.C., and M.P. Coutts. 1998. Deflection of Tree Roots by Rigid Barriers. Arboriculture Research and Information Note 143/98/SILN. 5 pp.

Nowak, D.J., M. Kuroda, and D.E. Crane. 2004. Tree mortality rates and tree population projection in Baltimore, Maryland, USA. Urban Forestry \& Urban Greening 2:139-148.

Numbere, T.E., F.D. Morrison, and R.W. Campbell. 1992. Effects of uniconazole, paclobutrazol, and flurprimidol on the control of young apple tree (Malus domestica) growth. Plant Growth Regulator Society of America Quarterly 20:65-75.

O'Callaghan, D.P., and O. Kelly. 2005. Tree-related subsidence: Pruning is not the answer. Journal of Building Approval 1:113-129.

Osmond, D.L., and D.H. Hardy. 2004. Characterization of turf practices in five North Carolina Communities. Journal of Environmental Quality 33:565-575.

O'Sullivan, M.F., and R.M. Ritchie. 1993. Tree stability in relation to cyclic loading. Forestry 66:69-82.

Peper, P.J. 1998. Comparison of root barriers installed at two depths for reduction of white mulberry roots in the soil surface. pp. 82-93. In: G. Watson and D. Neely (Eds.). The Landscape Below Ground II. International Society of Arboriculture, Champaign, Illinois, U.S.

Peper, P.J., and S. Mori. 1999. Root barrier and extension casing effects on Chinese hackberry. Journal of Arboriculture 25:1-7.

Percival, G., and J. Gerritsen. 1998. The influence of plant growth regulators on root and shoot growth of containerized trees following root removal. Journal of Horticultural Science \& Biotechnology 73:353-359.

Percival, G.C. 2004. Sugar feeding enhances root vigor of young trees following containerization. Journal of Arboriculture 30:357-364.

Percival, G.C., and G.A. Fraser. 2005. Use of sugars to improve root growth and increase transplant success of birch (Betula pendula Roth.). Journal of Arboriculture 31:66-78.

Percival, G.C., and S. Barnes. 2004. Auxins and water-retaining polymer root dips affect survival and growth of newly transplanted bare-rooted European beech and silver birch. Journal of Environmental Horticulture 22:183-188.
Percival, G.C., and S. Barnes. 2007. The influence of carbohydrates, nitrogen fertilizers and water-retaining polymer root dips on survival and growth of newly transplanted bare-rooted silver birch (Betula pendula Roth.) and European beech (Fagus sylvatica L.). Arboricultural Journal 30:223-244.

Percival, G.C., G.A. Fraser, and S. Barnes. 2004. Soil injections of carbohydrates improve fine root growth of established urban trees. Arboricultural Journal 28:95-101.

Philipson, J.J., and M.P. Coutts. 1977. The influence of mineral nutrition on the root development of trees II. The effect of specific nutrient elements on the growth of individual roots of Sitka spruce. Journal of Experimental Botany 28:864-871.

Piri, T. 1998. Effects of vitality fertilization on the growth or Heterobasidion annosum in Norway spruce roots. European Journal of Forest Pathology 28:391-397.

Pittenger, D., and D. Hodel. 2009. Six-year evaluation of circular root barriers on two tree species. Arboriculture \& Urban Forestry 35:41-46.

Pohls, O., N.G. Bailey, and P.B. May. 2004. Study of root invasion of sewer pipes and potential ameliorative techniques. Acta Horticulturae 643:113-121.

Ponder, F. Jr. 2000. Survival and growth of planted hardwoods in harvested openings with first-order lateral root differences, root-dipping, and tree shelters. Northern Journal of Applied Forestry 17:45-50.

Popoola, T.O.S., and R.T.V. Fox. 1996. Effect of root damage on honey fungus. Arboricultural Journal 20:329-337.

Prager, C.M., and G.P. Lumis. 1983. IBA and some IBA-synergist increases of root regeneration of landscape-sized trees. Journal of Arboriculture 9:117-123.

Prasad, R., and P.R. Moody. 1974. A preliminary study on the chemical control of maple roots (Acer saccharinum L.) with herbicides. Report, Chemical Control Research Institute. 10 pp.

Pryke, J.F.S. 1979. Trees and buildings. Arboricultural Journal 3:388-396.

Qu, L., A.M. Quoreshi, and T. Koike. 2003. Root growth characteristics, biomass, and nutrient dynamics of seedlings of two larch species raised under different fertilization regimes. Plant and Soil 255:293-302.

Rahardjo, H., F.R. Harnas, E.C. Leong, P.Y. Tan, Y.K. Fong, and E.K. Sim. 2009. Tree stability in an improved soil to withstand wind loading. Urban Forestry \& Urban Greening 8:237-247.

Rahman, M.A., J.G. Smith, P. Stringer, and A.R. Ennos. 2011. Effect of rooting conditions on the growth and cooling ability of Pyrus calleryana. Urban Forestry \& Urban Greening 10:185-192.

Randrup, T. 2000. Occurrence of tree roots in Danish municipal sewer systems. Arboricultural Journal 24:283-306.

Randrup, T.B., E.G. McPherson, and L.R. Costello. 2003. A review of tree root conflicts with sidewalks, curbs, and roads. Urban Ecosystems 5:209-225.

Rathjens, R.G., T.D. Sydnor, and D.S. Gardner. 2009. Evaluating root crown excavation as a treatment for deeply-planted landscape trees. Arboriculture \& Urban Forestry 35:287-293

Redmond, D.R. 1957. Infection courts of butt-rotting fungi in balsam fir. Forest Science 3:15-21.

Reichwein, S. 2003. Root growth under pavements - results of a field study. pp. 132-137. In: H. Balder, K. Strauch, and G.F. Bachhaus (Eds.). Second International Symposium on Plant Health in Urban Horticulture. Senate for Urban Development, Berlin, Germany. 
Reichwein, S., 2002. Baumwurzeln unter Verkehrsflächen. Untersuchungen zu Schäden an Verkehrsflächen und Ansätze zur Schadensbehebung und Schadensvermeidung. Institut für Grünplanung und Gartenarchitektur. Beiträge zur räumlichen Planung Heft 66. Schriftenreihe des Fachbereichs Landschaftsarchitektur und Umweltentwicklung. Hannover, Germany.

Ridgers, D., K. Rolf, and Ö. Stål. 2006. Management and planning solutions to lack of resistance to root penetration by modern PVC and concrete sewer pipes. Arboricultural Journal 29:269-270.

Riedacker, A. 1978. Etude de la déviation des racines horizontales ou obliques issues de boutures de peuplier qui rencontrent un obstacle: Applications pour la conception de conteneurs. Annales des Sciences Forestieres 35:1-18.

Rieger, M., and F. Marra. 1994. Responses of young peach trees to root confinement. Journal of the American Society for Horticultural Science 119:223-228.

Robinson, R.M., and D.J. Morrison. 2001. Lesion formation and host response to infection by Armilaria ostoyae in the roots of western larch and Douglas-fir. Forest Pathology 31:371-385.

Rolf, K., and Ö. Stål. 1994. Tree roots in sewer systems in Malmo, Sweden. Journal of Arboriculture 20:329-335.

Rolf, K., Ö. Stål, and H. Schroeder. 1995. Tree roots and sewer systems. pp. 68-71. In: Trees and Building Sites. International Society of Arboriculture, Champaign, Illinois, U.S.

Roppolo, D.J., Jr., and R.W. Miller. 2001. Factors predisposing urban trees to sunscald. Journal of Arboriculture 27:246-254.

Ruehle, J.L., and P.P. Kormanik. 1986. Lateral Root Morphology: A Potential Indicator of Seedling Quality in Northern Red Oak. USDA Forest Service Southeastern Forest Experiment Station Research Note SE-334.

Rytter, L., T. Ericsson, and R.M. Rytter. 2003. Effects of demanddriven fertilization on nutrient use, root:plant ratio and field performance of Betula pendula and Picea abies. Scandinavian Journal of Forest Research 18:401-415.

Santamour, F.S., Jr. 1985. Trunk wood discoloration and decay following root wounding. Journal of Arboriculture 11:257-262.

Schultz, R.C., and J.R. Thompson. 1997. Effect of density control and undercutting on root morphology of $1+0$ bare root hardwood seedlings: five-year field performance of rootgraded stock in the central USA. New Forests 13:301-314.

Sheriff, D.W., and E.K.S. Nambiar. 1995. Effect of subsoil compaction and three densities of simulated root channels in the subsoil on growth, carbon gain, and water uptake of Pinus radiata. Australian Journal of Plant Physiology 22:1001-1013.

Shigo, A.L. 1972. Successions of microorganisms and patterns of discoloration and decay after wounding in red oak and white oak. Phytopathology 62:256-259.

Shigo, A.L. 1977. Compartmentalization of Decay in Trees. USDA Forest Service Agriculture Information Bulletin Number 405. $70 \mathrm{pp}$.

Shigo, A.L. 1979a. Compartmentalization of decay associated with Heterobasidion annosum in roots of Pinus resinosa. European Journal of Forest Pathology 9:341-347.

Shigo, A.L. 1979b. Tree Decay: An Expanded Concept. USDA Forest Service Agriculture Information Bulletin Number 419. 72 pp.

Shigo, A.L. 1986. A New Tree Biology Dictionary. Shigo and Trees Associates, Durham, New Hampshire, U.S. 132 pp.

Shigo, A.L. 1991. Modern Arboriculture. Shigo and Trees Associates, Durham, New Hampshire, U.S. 424 pp.
Silva, D.D., M.E. Kane, and R.C. Beeson, Jr. 2012. Changes in Root and Shoot Growth and Biomass Partition Resulting from Different Irrigation Intervals for Ligustrum japonicum Thunb. Hortscience 47:1634-1640.

Smiley, E.T, S.J. Lilly, and P. Kelsey. 2007. Best Management Practices: Tree and shrub fertilization. International Society of Arboriculture, Champaign, Illinois, U.S.

Smiley, E.T. 2005. Root growth near vertical root barriers. Journal of Arboriculture 31:150-152.

Smiley, E.T. 2006. Root collar excavation for urban landscape trees. pp. 49-50. In: Trees and Planting: Getting the Roots Right, The Morton Arboretum, Lisle, IL. Accessed 05/21/2013. <www.mortonarb.org/deeptreeroots/pdf/GRR_Proceedings.pdf\#TOC>

Smiley, E.T. 2008a. Comparison of methods to reduce sidewalk damage from tree roots. Arboriculture \& Urban Forestry 34:179-183.

Smiley, E.T. 2008b. Root pruning and stability of young willow oak. Arboriculture \& Urban Forestry 34:123-128.

Smiley, E.T., A. Key, and C. Greco. 2000. Root barriers and windthrow potential. Journal of Arboriculture 26:213-217.

Smiley, E.T., L. Calfee, B.R. Fraedrich, and E.J. Smiley. 2006. Comparison of structural and noncompacted soils for trees surrounded by pavement. Arboriculture \& Urban Forestry 34:164-169.

Smiley, E.T., L. Wilkinson, and B.R. Fraedrich. 2009. Root growth near vertical root barriers after seven years. Arboriculture \& Urban Forestry 35:23-26.

Smith, K., P. May, and R. White. 2010. Above and belowground growth of Corymbia maculata in a constructed soil: The effect of profile design and organic amendment. Arboriculture \& Urban Forestry 36:11-17.

Smith, P.F. 1965. Effect of nitrogen source and placement on the root development of Valencia orange trees. Proceedings of the Florida State Horticultural Society 78:55-59.

Sokalska, D.I., D.Z. Haman, A. Szewczuk, J. Sobota, and D. Deren. 2009. Spatial root distribution of mature apple trees under drip irrigation system. Agricultural Water Management 96:917-924.

Solfjeld, I., and P.A. Pedersen. 2006. Growth of Betula pendula Roth. the first season after transplanting at two phenological stages. Urban Forestry \& Urban Greening 5:101-106.

Stål, Ö. 1992. Trädrötter och ledningar (Roots and pipes). Svenska vatten-och avloppsverksföreningen, VAV. Report 1992-14.

Stål, Ö. 1995. Trädrötter och avloppsledningar. En fordjupad undersokning av rotproblem i nya avloppsledningar. Svenska Vatten och Avloppsverksföreningen. VA-FORSK Rapport Nr. 1995-11.

Stål, Ö. 1998. The interaction of tree roots and sewers: The Swedish experience. Arboricultural Journal 22:359-367.

Starbuck, C., D.K. Struve, and H. Mathers. 2005. Bareroot and balled-and-burlapped red oak and green ash can be summer transplanted using the Missouri gravel bed system. HortTechnology 15:122-127.

Stewart, M., and R. Sands. 1996. Comparative water relations of trees in clay soils and the potential for building damage. Arboricultural Journal 20:313-328.

Stokes, A., T. Fourcaud, J. Hruska, J. Cermak, N. Nadezhdina, V. Nadezhdin, and L. Praus. 2002. An evaluation of different methods to investigate root system architecture of urban trees in situ. I. Ground-penetrating radar. Journal of Arboriculture 28:2-10.

Stone, E.L. 1974. The communal root system of red pine: Growth of girdled trees. Forest Science 20:294-305. 
Struve, D.K., and B.C. Moser. 1984. Auxin effects on root regeneration of scarlet oak seedlings. Journal of the American Society of Horticultural Science 109:91-95.

Sundstrom, E., and M. Keane. 1999. Root architecture, early development and basal sweep in containerized and bare-rooted Douglas fir (Pseudotsuga menziesii). Plant and Soil 217:65-78.

Sutton, R.F., and R.W. Tinus. 1983. Root and root system terminology. Forest Science 29(4):supplement (Monograph 24).

Swiecki, T.J. 1990. A delicate balance: Impacts of diseases and insects on the health of California oaks. Fremontia 18:58-63.

Switzer, G.L. 1960. Exposure and planting depth effects on loblolly pine planting stock on poorly drained sites. Journal of Forestry 58:390-391.

Sydnor, T.D., D. Gamstetter, J. Nichols, B. Bishop, J. Favorite, C. Blazer, and L. Turpin. 2000. Trees are not the root of sidewalk problems. Journal of Arboriculture 26:20-29.

Symeonidou, M.V., and P.G. Buckley. 1997. The effect of preplanting desiccation on survival and growth of Prunus cerasifera seedlings and the relationship of physiological indicators at planting with field performance and survival. Russian Journal of Plant Physiology 44:514-517.

Tamasi, E., A. Stokes, B. Lasserre, F. Danjon, S. Berthier, T. Fourcaud, and D. Chiatante. 2005. Influence of wind loading on root system development and architecture in oak (Quercus robur L.) seedlings. Trees 19:374-384.

Tate, R.L. 1980. Detection, description and treatment of girdling roots on urban Norway maple tree. pp. 83-87. In: D.F. Karnosky (Ed.). METRIA:3 Proceedings.

Tate, R.L. 1981. Characteristics of girdling roots on urban Norway maples. Journal of Arboriculture 7:268-270.

Tian, S., and W.D. Ostrofsky. 2007. Butt and root decay in precommercially thinned spruce-fir stands. Northern Journal of Applied Forestry 24:129-133.

Tippett, J.T., A.L. Bogle, and A.L. Shigo. 1982. Response of balsam fir and hemlock roots to injuries. European Journal of Forest Pathology 12:357-364.

Tippett, J.T., and A.L. Shigo. 1980. Barrier zone anatomy in red pine roots invaded by Heterobasidion annosum. Canadian Journal of Forestry Research 10:224-232.

Tippett, J.T., and A.L. Shigo. 1981. Barriers to decay in conifer roots. European Journal of Forest Pathology 11:51-59.

Townsend, K., D. Ham, A. Miller, and T. Chesnut. 1997. Soil Aeration Systems: Do they really improve tree root zone conditions under fill and paving? Accessed 05/21/2013. <www.clemson. edu/cafls/departments/horticulture/research/ornamental/landscape/soil_aeration_systems.html>

Tryon, P.R., and F.S. Chapin III. 1983. Temperature control over root growth and root biomass in taiga forest trees. Canadian Journal of Forest Research 13:827-833.

Tschaplinski, T.J., and T.J. Blake. 1985. Effects of root restriction on growth correlations, water relations, and senescence of alder seedlings. Physiologia Plantarum 64:167-176.

Tworkoski, T.J., M.E. Engle, and P.T. Kujawski. 1996. Growth regulatory effects and soil concentration of controlled-release Trifluralin applied to roots of yellow poplar and red oak. Journal of the American Society of Horticultural Science 121:461-465.

Urban, J. 1992. Bringing order to the technical dysfunction within the urban forest. Journal of Arboriculture 18:85-90.
Urban, J. 2008. Up by Roots: Healthy Soils and Trees in the Built Environment. International Society of Arboriculture, Champaign, Illinois, U.S. 479 pp.

Verzilov, V. 1970. Treatment of trees with growth regulators during transplanting. Soviet Science Review 1:157-161.

Viswanathan, B., A. Volder, W.T. Watson, and J.A. AitkenheadPeterson. 2011. Impervious and pervious pavements increase soil $\mathrm{CO}_{2}$ concentrations and reduce root production of American sweetgum (Liquidambar styraciflua). Urban Forestry \& Urban Greening 10:133-139.

Volder, A., T. Watson, and B. Viswanathan. 2009. Potential use of pervious concrete for maintaining existing mature trees during and after urban development. Urban Forestry \& Urban Greening 8:249-256.

von der Heide-Spravka, K.G., and G.W. Watson. 1990. Directional variation in growth of trees. Journal of Arboriculture 16:169-173.

Vrecenak, A.J., M.C. Vodak, and L.E. Fleming. 1989. The influence of site factors on the growth of urban trees. Journal of Arboriculture 15:206-209.

Wagar, J.A. 1985. Reducing surface rooting of trees with control planters and wells. Journal of Arboriculture 11:165-171.

Wagar, J.A., and A.L. Franklin. 1994. Sidewalk effects on soil moisture and temperature. Journal of Arboriculture 20:237-238.

Wagar, J.A., and P.A. Barker. 1983. Tree root damage to sidewalks and curbs. Journal of Arboriculture 6:95-105.

Wahlenberg, W.G. 1929. Modification of western yellow pine root systems by fertilizing the soil at different depths in the nursery. Journal of Agricultural Research 39:137-146.

Warren, S.L. 1993. Growth and nutrient concentration in flowering dogwood after nitrogen fertilization and dormant root pruning. Journal of Arboriculture 19:57-63.

Watson, G. 1985. Tree size affects root regeneration and top growth after transplanting. Journal of Arboriculture 11:37-40.

Watson, G. 2004. Effect of transplanting and paclobutrazol on root growth of 'Green Column' black maple and 'Summit' green ash. Journal of Environmental Horticulture 22:209-212.

Watson, G. 2008. Discoloration and decay in severed tree roots. Arboriculture \& Urban Forestry 34:260-264.

Watson, G.W. 1987. Are auxins practical for B\&B trees? American Nurseryman 166:183-184.

Watson, G.W. 1996. Tree root system enhancement with paclobutrazol. Journal of Arboriculture 22:211-217.

Watson, G.W. 1998. Tree growth after trenching and compensatory crown pruning. Journal of Arboriculture 24:47-53.

Watson, G.W. 2006. The effect of paclobutrazol treatment on starch content, mycorrhizal colonization, and fine root density of white oaks (Quercus alba L.). Arboriculture \& Urban Forestry $32: 114-117$

Watson, G.W. 2009. Desiccation tolerance of green ash and sugar maple fine roots. Journal of Environmental Horticulture 27:229-233.

Watson, G.W., and E.B. Himelick. 1982a. Seasonal variation in root regeneration of transplanted trees. Journal of Arboriculture 8:305-310.

Watson, G.W., and E.B. Himelick. 1982b. Root distribution of nursery trees and its relationship to transplanting success. Journal of Arboriculture 8:225-229. 
Watson, G.W., and E.B. Himelick. 2004. Effects of soil pH, root density, and tree growth regulator treatments on pin oak chlorosis. Journal of Arboriculture 30:172-177.

Watson, G.W., and S. Clark. 1993. Regeneration of girdling roots after removal. Journal of Arboriculture 19:278-280.

Watson, G.W., S. Clark, and K. Johnson. 1990. Formation of girdling roots. Journal of Arboriculture 16:197-202.

Watson, W.T., D.N. Appel, M.A. Arnold, and C.M. Kenerley. 2006. Spatial distribution of Malus root systems in irrigated, trellised orchards. Journal of Horticultural Science \& Biotechnology 81:745-753.

Weller, F. 1966. Horizontal distribution of absorbing roots and the utilization of fertilizers in apple orchards. Erwobstbsobstbau $8: 181-184$

Wells, C., K. Townsend, J. Caldwell, D. Ham, E.T. Smiley, and M. Sherwood. 2006. Effects of planting depth on landscape tree survival and girdling root formation. Arboriculture \& Urban Forestry 32:305-311.

Wells, C.A., D. Whigham, and H. Lieuth. 1972. Investigation of mineral nutrient cycling in an upland piedmont forest. Journal of the Elisha Mitchell Scientific Society 88:66-78.

White, D.A., and G.A. Kile. 1993. Discoloration and decay from artificial wounds in 20-year-old Eucalyptus regnans. European Journal of Forest Pathology 23:431-440.

Whitney, R.D. 1967. Comparative susceptibility of large and small spruce roots to Polyporous tomentosus. Canadian Journal of Botany 45:2227-2229.

Wilcox, H. 1955. Regeneration of injured root systems in Noble fir. Botanical Gazette 116:221-234.

Wilson, A.D., and D.G. Lester. 2002. Trench inserts as long-term barriers to root transmission for control of oak wilt. Plant disease $86: 1067-1074$

Wilson, B.F. 1967. Root growth around barriers. Botanical Gazette 128:79-82.

Witherspoon, W.R., and G.P. Lumis. 1986. Root regeneration of Tilia cordata cultivars after transplanting in response to root exposure and soil moisture levels. Journal of Arboriculture 12:165-168.

Witt, H.H. 1997. Root growth of trees as influenced by physical and chemical soil factors. Acta Horticulturae 450:205-214.

Wong, T.W., J.E.G. Good, and M.P. Denne. 1988. Tree root damage to pavements and kerbs in the city of Manchester. Arboricultural Journal 12:17-34.

Yeager, T.H., and R.D. Wright. 1981. Influence of nitrogen and phosphorus on shoot:root ratio of Ilex crenata Thunb. 'Helleri.' HortScience 16:564-565.

Yelenosky, G. 1964. Tolerance of trees to deficiencies of soil aeration. Proceedings of the International Shade Tree Conference 40:27-147.
Gary W. Watson (corresponding author)

The Morton Arboretum

4100 Illinois Route 53

Lisle, Illinois 60532, U.S.

gwatson@mortonarb.org

Angela M. Hewitt

The Morton Arboretum

4100 Illinois Route 53

Lisle, Illinois 60532, U.S.

Melissa Custic

The Morton Arboretum

4100 Illinois Route 53

Lisle, Illinois 60532, U.S.

Marvin Lo

The Morton Arboretum

4100 Illinois Route 53

Lisle, Illinois 60532, U.S.

Zusammenfassung. Das Wurzelsystem von nahezu allen Bäumen in bebauten Bereichen ist den Einflüssen von menschlichen Aktivitäten ausgesetzt, welche die Baumgesundheit beeinflussen und die Langlebigkeit reduzieren. Diese Einflüsse sind von der Frühphase der Baumschulentwicklung bis durch das ganze Leben der Bäume präsent. Durch Baumaßnahmen oder Wurzelverlust reduzierte Wurzelsysteme können die Stabilität beeinflussen und den Stress vergrößern. Natürliche Infektionen von Wurzeln bei Straßenbäumen durch Abtrennen führten nachweislich nicht zu extensiver Fäulnis. Wurzeln geraten wegen ihrer Nähe zur Infrastruktur in Konflikt mit der urbanen Umgebung. Strategien zur Bereitstellung von Wurzelraum unter den Pflasterflächen und zur Reduzierung von angehobenen Pflasterflächen wurden entwickelt, aber die Strategien zum Schutz von Fundament- und Abwasserrohrschäden sind begrenzt auf wachsende Separation oder verbesserte Konstruktion.

Resumen. Los sistemas de raíces de casi todos los árboles en el entorno construido están sujetos a los impactos de las actividades humanas que pueden afectar su salud y reducir su longevidad. Estas influencias están presentes desde las primeras etapas de desarrollo en viveros y luego durante toda la vida del árbol. Sistemas de raíces reducidos, pérdida o constricción de las mismas pueden disminuir la estabilidad del árbol y aumentar el estrés. La infección natural de las raíces de los árboles urbanos después de su ruptura no se ha demostrado que conduzca a un extensivo decaimiento. Las raíces a menudo entran en conflicto con la infraestructura en las zonas urbanas debido a la proximidad. Se han desarrollado alternativas para proporcionar espacio para las raíces bajo las aceras y reducir la aglomeración, pero las estrategias para la prevención de daños por pavimentación y tubería de alcantarillado se limitan a aumentar la separación o la mejora de la construcción. 